\title{
Kadınların Cinsiyetçiliğe Tepkileri: Meşrulaştırma, Kendini Suskunlaştırma, Yüzleşme ve Kolektif Hareket
}

\author{
Nuray Sakall ${ }^{1}$ \\ Orta Doğu Teknik Üniversitesi
}

\begin{abstract}
Özet
Kadınlar günlük yaşamlarında cinsiyetçiliğin birçok farklı türüne maruz kalır. Kadınların cinsiyetçiliği fark etme düzeyleri ve verdikleri tepkiler farklılık gösterebilir. Kadınların verdikleri bu farklı tepkiler ise kendilerinin veya cinsiyetçiliğin değişmesini farklı şekillerde etkiler. Bu tarama makalesinin amacı kadınların cinsiyetçiliğe karşı tepkilerine ilişkin alanyazın araştırmalarının cinsiyetçilik farkındalığı düşük/yüksek ve cinsiyetçiliğe tepki vermede pasif/aktif olma boyutları kapsamında derlenmesidir. Alanyazında belirtilen tepkiler cinsiyetçilik farkındalığını içerecek şekilde pasif olarak var olanı kabul etme ve onaylama durumundan aktif olarak kolektif hareketlere katılmaya kadar dört ana başlık altında sunulmuştur. Bunlar (1) cinsiyetçilik farkındalı̆̆ı olmayıp ya da farkındalığ düşük olup, var olan cinsiyet sistemini olduğu gibi kabullenme ve meşrulaştırma; (2) cinsiyetçilik farkındalığı olup, cinsiyetçiliğe ilişkin olumsuz duygular yaşasa bile harekete geçmeyip kendini suskunlaştırma; (3) cinsiyetçilik farkındalığı olup, cinsiyetçi tutum ve davranışlara karşı koyma yani cinsiyetçilikle yüzleşme; ve (4) cinsiyetçilik farkındalığı olup, kolektif hareketlerde bulunma şeklinde ele alınmıştır. Cinsiyetçiliği kabullenme ve meşrulaştırma, kendini suskunlaştırma, cinsiyetçilikle yüzleşme ve kolektif hareketler olarak ele alınan bu dört ana tepkiyi etkileyen unsurlar olarak sosyal baskınlık, sistemi meşrulaştırma, sağ kanat yetkecilik, reddedilme hassasiyeti, cinsiyetçiliğin türü, failin tanıdıklı̆̆ı, ortamın özellikleri, ödül-bedel algısı, kadın kimliğiyle özdeşleşme ve adaletsizlik algısı vb. ele alınmış ve ilgili ana başlıklar altında sunulmuştur. Son olarak, bu dört farklı tepkinin kadınlar üzerindeki bireysel ve grup temelli olası olumlu veya olumsuz çıktıları ele alınmıştır.
\end{abstract}

Anahtar kelimeler: Cinsiyetçiliğe tepkiler, meşrulaştırma, kendini suskunlaştırma, yüzleşme, kolektif hareket

\begin{abstract}
Women are exposed to a variety of sexist behaviors in their daily lives. They may present different responses to these sexist behaviors. The response differences may cause positive or negative outcomes to their lives and social change in sexism. The purpose of the article is to review the literature on women's responses to sexism under two main dimensions as the level of awareness of sexism and passive/active strategies against sexism. Depending on the literature on sexism, these responses may vary from passive acceptance to collective action, and they can be grouped under four main titles as (1) acceptance and justification of sexism without awareness of sexism, (2) self-silencing with awareness of sexism, (3) confronting sexism with awareness of sexism, and (4) collective behavior with awareness of sexism. Under these four main responses, correlated factors such as social dominance, system justification, right-wing authoritarianism, rejection sensitivity, type of sexist behavior, acquaintance, characteristics of the situation, perception of costs and benefits, social identification, and perception of fairness are presented. Finally, probable individual and group based positive or negative outcomes of these four types of responses on women are covered.
\end{abstract}

Keywords: Responses to sexism, justification, self-silencing, confrontation, collective action

Yazışma Adresi: 'Prof. Dr., Nuray Sakallı, Orta Doğu Teknik Üniversitesi, Fen-Edebiyat Fakültesi, Psikoloji Bölümü, Beşeri Bilimler Binası 06800 Çankaya / Ankara, nurays@metu.edu.tr, ORC-ID: 0000-0003-4984-8427

Gönderim Tarihi: 05.09.2019

Kabul Tarihi: 20.02.2021 
Günlük yaşantılarında kadınlar, yakın ilişkiler, aile, eğitim, iş yeri, politika, medya ve hukuki sistem gibi farklı ortamlarda birçok cinsiyetçi olayla karşılaşır. Çok farklı şekillerde oluşan bu olaylar, kadın-erkek farklılıklarının abartılarak, erkeklerin kadınlardan daha üstün olduğunu ve kadınların erkeklerin tamamlayıcısı olduğunu vurgular. Bu cinsiyetçilik, yetkinlik sorgulama (örn., “Sen bunu yapabilecek misin?”), küçümseme-aşağılama (örn., "Elinin hamuru ile erkek işine karışma") ve cinsiyetçi dil veya şakalar şeklinde daha gizli davranışlarla kendini gösterebileceği gibi, sözel şiddet, takip etme ve cinsel taciz gibi çok net saldırgan davranışlarla da kendini gösterebilir (Kaiser ve Miller, 2004). Hatta kadın, cinsel bir nesne olarak sadece vücuda ya da cinsel işlevselliğine indirgenebilir (Fredrickson ve Roberts, 1997; Swim ve ark., 2001). Peki günlük yaşamlarında cinsiyetçiliğe maruz kalan kadınlar ne tür tepkiler verir? Kadınların cinsiyetçiliği fark etme düzeyleri tepkilerini değiştirir mi? Kadınların verdikleri farklı tepkileri ne tür değişkenler etkiler? Bu tepkilerin bireysel veya grup olarak kadınlara olası olumlu veya olumsuz çıktıları nelerdir? $\mathrm{Bu}$ makalenin amacı belirtilen bu sorular çerçevesinde alanyazındaki farklı araştırmaları inceleyerek, kadınların cinsiyetçiliğe ne tür tepkiler verdiklerine ilişkin bir yazın taraması sunmaktır. Özellikle sosyal psikoloji alanında yapılan çalıșmalara ağırlık verilerek yazılan bu tarama yazısı, kadın ve cinsiyetçilik konuları ile ilgilenen araştırmacılara ve uygulamacılara yol gösterici bir kılavuz niteliğinde olabilir. Araştırmacılar ve uygulamacılar ilgili yayınları ve ele alınan değişkenleri değerlendirme firsatı yakalayabilir, olası araștırma soruları ve hipotezleri üretebilir ve cinsiyetçiliğe tepkiler konusunda yaşanan sorunları çözmek için ipuçları bulabilir.

\section{Kadınların Cinsiyetçiliğe Tepkileri}

Cinsiyetçilik, kısaca, cinsiyete dayalı olumsuz tutumlar ve davranışlar şeklinde tanımlanabilir. Sosyal psikoloji alanında cinsiyetçilik konusunda genel olarak erkeğin kadından üstün görülmesi ile kadın-erkek eşitsizliği ve bunun sonucunda oluşan kadına karşı önyarg1 ve ayrımcılık konularına odaklanılmaktadır (Eagly ve Mladinic, 1989; Glick ve Fiske, 1996; Rudman ve Glick, 2001). Cinsiyetçilik yazınındaki çalışmalar çoğunlukla cinsiyet rollerine ilişkin kalıpyargılar, kadına yönelik olumsuz tutumlar/davranışlar, kadınlara uygulanan şiddet, aile, sosyal, yakın ilişki veya iş ortamında kadınlara yapılan ayrımcılıklar ve kadınla ilişkili namus algısı gibi konuları içermektedir (bkz. Sakallı-Uğurlu, 2003). Bunun yanı sıra erkeklere ilişkin tutumlar, erkeksilik, erkeklik ve erkekliğin olumsuz yönleri (bkz. Sakallı ve Türkoğlu, 2019) gibi konular da cinsiyetçilik kapsamında ele alınsa bile bu makalede cinsiyetçilik kavramı kadınla ilintili olarak sunulacaktır. Çünkü dezavantajlı konumlarıyla sosyal psikoloji alanında yapılmış birçok çalışmada (örn., Crosby, 1976; Radke ve ark., 2016) azınlık olarak ele alınan kadınların cinsiyetçiliğe karşı tepkilerini incelemenin güncel kadın sorunlarını anlamaya ve çözmeye yardımcı olacağı düşünülmektedir.

Alanyazına bakıldığında, cinsiyetçilik karşısında kadınların farklı deneyimler yaşadıkları ve farklı tepkiler verdikleri görülmektedir (Ayres ve ark., 2009; Radke ve ark., 2016). Kadınlar, cinsiyetçi davranışları karşısında görmezden gelme, yanlış anladığını düşünüp cinsiyetçi algılamama, yaşadıklarını önemsizleştirme, kendini suçlama, yapılanlara ısrarcı bir şekilde suskun kalma, cinsiyetçi tavır ve davranışlar gösterenlerden uzaklaşma, şakaya vurma, alaya alma, dur deme, itiraz etme, faile yaptığının yanlış olduğunu söyleme, faili şikâyet etme, diğerlerinden sosyal destek ve yardım isteme, kurumsal ve toplumsal destek arama gibi farklı baş etme yollarıyla tepkiler verebilir (Fitzgerald ve ark., 1995; Knapp ve ark., 1997; Major ve ark., 2002).

Araştırmacılar, yukarıda belirtilen kadın tepkilerini sınıflandırmaya çalıșmış ve bazı boyutlar önermiştir. Örneğin, Magley (2002) kadınların cinsel tacize tepkilerini bilişsel /davranışsal ve uğraşma /uğraşmama boyutlarında ele almıştır. Benzer tepkiler doğrudan /dolaylı girişkenlik ve tek başına /diğerlerinin yardımıyla mücadele (Gutek ve Koss, 1993) ya da benlik odakll veya cinsel tacizci/olay odakl (Knapp ve ark., 1997; Wasti ve Cortina, 2002) gibi farklı boyutlarla incelenmiştir. Bu makalede cinsel tacizi de içeren cinsiyetçilik konusu ele alındığı için cinsiyetçiliğe tepkileri derlemede farklı boyutların tercih edilmesi gerektiği düşünülmüștür. Belirtilecek olan bu boyutlar ilgili alanyazındaki konuları daha kolay organize edebilmek amaciyla sunulmuştur.

Gruplar arası ilişkiler kapsamında, kişilerin içinde bulundukları dezavantajlı durumlarının farkında olmalarının önemi ve içinde bulundukları durumu kabullenmeleri gibi konulardan bahsedilmiş; grup üyelerinin yaşadıkları psikolojik ve sosyal çatışmaları bilişsel işlemleri içeren sosyal yaratıcılık, bireysel hareketlilik ve sosyal değişim gibi farklı stratejiler kullanarak değiştirebilecekleri belirtilmiştir (Tajfel ve Turner, 1979; Wright ve ark., 1990). Gruplar arası ilişkiler alanyazınındaki bu açıklamalardan esinlenerek ve kadınların cinsiyetçiliğe verdiği tepkilere dair alanyazın (Fitzgerald ve ark., 1995; Major ve ark., 2002) göz önünde bulundurularak, bu tarama yazısında (1) cinsiyetçilik farkındalığının seviyesi ve (2) cinsiyetçiliğe tepki vermede pasiflaktif olma boyutlarının kullanılması uygun bulunmuştur. Özetle, alanyazındaki konuların belirli bir çerçevede sunulabilmesi amacıyla, farklı operasyonel tanımlarla ele alınan kadın tepkileri, cinsiyetçilik farkındalığının düzeyini içererek, pasif bir şekilde var olanı kabul etme ve onaylama durumundan, aktif olarak kolektif hareketlere katılmaya ka- 
dar bir yelpazede derlenerek sunulacaktır. Alanyazındaki çalışmalar şu dört ana başlık altında ele alınacaktır:

(1) Cinsiyetçilik farkındalığı olmayıp ya da düşük olup, var olan cinsiyet sistemini olduğu gibi kabullenme ve meşrulaştırma (farkındalık yok ya da düşük; pasif);

(2) Cinsiyetçilik farkındalığı olup, cinsiyetçiliğe ilişkin olumsuz duygular yaşasa bile harekete geçmeyip kendini suskunlaştırma (farkındalık düşük veya var; pasif)

(3) Cinsiyetçilik farkındalığ1 olup, cinsiyetçi tutum ve davranışlara bireysel olarak doğrudan karşı koyma; cinsiyetçilikle yüzleşme (farkındalık var; aktif)

(4) Cinsiyetçilik farkındalığı yüksek olup, kolektif hareketlerde bulunma (farkındalık var; aktif).

\section{Cinsiyetçiliği Kabullenme ve Meşrulaștırma}

Yurt içinde ve dışında yapılan çalışmalar, kadınların olumsuz tutumlara ve cinsiyetçi davranışlara maruz kaldığını gösterse de (örn., Sakall1-Uğurlu, 2003; Swim ve ark., 2001), bazı kadınların dezavantajlı ve bastırılmış grup olduklarına dair açık ipuçlarıyla karşılaşmadıkça cinsiyetçilik farkındalıklarının düşük olduğu görülmektedir (Brant ve ark., 1999; Downing ve Roush, 1985). Cinsiyetçiliğin getirdiği olumsuzlukların farkında olmayan ve cinsiyetçiliği içselleştiren kadınlar, var olan cinsiyet kalıpyargılarını ve cinsiyet eșitsizliğini pasif bir şekilde kabullenebilir (Szymanski ve ark., 2009; Zucker ve Bay-Cheng, 2010). Bu kadınlar, kültürel, kurumsal ve bireysel olarak yansıtılan cinsiyetçiliğin varlığını inkâr edebilirler. Kadın-erkek ilişkilerini ve cinsiyet rollerini olması gereken ve uyulması gerekli olan gelenek, töre ve sosyal değerler olarak kabul edebilirler. Uyum gösterdikleri ya da itaat ettikleri bu cinsiyet sisteminin adil olduğunu düşünüp, bu sistemi meşrulaştırabilir ve geleneksel cinsiyet rollerine uygun davranmayan kadınlardan (örn., feministler) uzaklaşıp, kolektif hareketlerden kaçınabilirler (Eagly ve Steffen, 1984). Bazı kadınlar, eşitlik arayışını ve kadın mücadelesini anlamakta zorlanarak "Ne için mücadele ediliyor ki?" sorusuyla diğer kadınları eleştirebilir; kadın ve erkeklerin doğuştan gelen biyolojik farklılıkları olduğunu ve bu farklılıkların sosyal rollere yansımasının doğal olduğunu savunabilirler (Radke ve ark., 2016).

Kadına dair gelenekselleşmiş kalıpyargılar ve roller ile özdeşleşen kadınların gösterdikleri bu meşrulaştırma ve uyma davranışları farklı sosyal psikolojik kuramlarla açıklanabilir. Bu kuramların başlıcaları, çelişik duygulu cinsiyetçilik, sistemi meşrulaştırma, sağ kanat yetkecilik ve sosyal baskınlık kuramlarıdır. İlk olarak, cinsiyetçiliği ölçmeye ve açıklamaya çalışan Çelişik Duygulu Cinsiyetçilik Kuramı (Glick ve Fiske, 1996; bkz. Sakallı-Uğurlu, 2003) ele alınabilir. Glick ve arkadaşlarına (2000) göre, kadınlara ilişkin olumsuz tutumlar, yani cinsiyetçi- lik, farklı düzeylerde olsa bile tüm ülkelerde görülmektedir. Ancak, cinsiyetçi sistemlerde kadınlara ilişkin bu olumsuz tutumlar ve davranışların yanı sıra kadınlara atfedilen birçok olumlu özellik de mevcuttur. Örneğin, kadınlar genellikle anaç, sevecen, naif, yardımsever ve bakım veren gibi sıfatlarla tanımlanmaktadır (Eagly ve Mladinic, 1989; Sakall1-Uğurlu ve ark., 2018). Dolayısıyla bu kurama göre, kadınlar hem olumlu hem de olumsuz şekilde değerlendirilmekte ve kadınlara ilişkin tutumlar, düşmanca ve korumacı olmak üzere, çelişik bir durumda olabilmektedir (Glick ve Fiske, 1996).

Çelişik Duygulu Cinsiyetçilik Kuramı'nı öneren Glick ve Fiske (2001) kadınlara ilişkin düşmanca ve korumacı cinsiyetçiliğin, cinsiyetçi sistemin korunmasına ve sürdürülmesine farklı açılardan katkı sağladığını belirtmektedir. Korumacı ataerkillik, cinsiyetler arası tamamlayıcı farklılaştırma ve heteroseksüel yakınlık içeren korumacı cinsiyetçilik ideolojisi, özellikle korumacı ataerkillik alt faktörü, erkeklere ellerinde bulundurdukları baskınlığı ve üstünlüğü olumlama olanağı sağlamaktadır. Erkekler, kadınları koruma, kollama ve kadınlara bakma sorumluluğunda olduklarını ve bu nedenle de bulundukları konumu hak ettiklerini düşünmektedir. Korumacı cinsiyetçilik, erkeklerin kadınları koruma ve kadınlara bakma sorumluluğu taşıdığı düşüncesiyle kendilerini kadınlara ve çocuklarına adamalarını ve böylece kendileri hakkında olumlu bir benlik imajı oluşturmalarını sağlamaktadır. Buna paralel olarak, kadınlar, kendileri için bu yükün altına giren erkeklerin daha üstün ve baskın konumda olmalarını çok doğal karşılamaktadır. Korumacı cinsiyetçilik, özünde, kadının düşük statüde olduğunu ve erkek egemenliğini savunmaktadır.

Düşmanca cinsiyetçilik, korumacı cinsiyetçiliğin toplumsal cinsiyet sistemini meşrulaştıran bu yapısına katkı sağlamaktadır. Baskıcı ataerkillik, cinsiyetler aras1 yarışmacı farklılaştırma ve düşmanca heteroseksüel ilişki alt faktörlerini kapsayan düşmanca cinsiyetçilik, gücü paylaşmak isteyen, eşitliği savunan ve geleneksel toplumsal rollere uymayan kadınların, erkeklerin onları korumasına, kollamasına ve onlara bakmasına şükretmedikleri için olumsuz tutumları ve kötü davranışları hak ettikleri düşüncesini içermektedir. Düşmanca cinsiyetçilik, kadına olumsuz bir tarzda had bildirmekteyken, korumacı cinsiyetçilik olumlu bir tonda kadınların ataerkilliğe karşı koyma motivasyonunun oluşmasına engel olmakta ya da var olan motivasyonun azalmasına katk1 sağlamaktadır (Glick ve Fiske, 2001).

Korumacı cinsiyetçiliğin algılanan olumlu tonu ile kadınlara, erkek gücünün kendi avantajlarına olduğu ve erkekler tarafindan kollanıp, korundukları hatırlatılmaktadır. Korumacı cinsiyetçiliği benimseyen kadınlar, kadın olmanın avantajlı yanlarına odaklanırlarsa; cinsiyet odaklı sosyal yapının meşru olduğunu algılarlarsa 
(Becker ve Wright, 2011; Connelly ve Heesacker, 2012) ve cinsiyet sistemini dengeli ve adil görürlerse yaşam memnuniyetleri de yükselmektedir (Hammond ve Sibley, 2011). Korumacı cinsiyetçiliğin onaylanması ile yaşam doyumu arasındaki bu olumlu ilişki farklı ülkelerde de bulunmuştur (Napier ve ark., 2010). Ekonomik ve sosyal açılardan erkeklere bağımlı olma durumu arttıkça kadınların, erkeklerin üstünlük ve baskınlığına karşı çıkma ve bunları protesto etme olasılıkları azalmaktadır. Korumacı cinsiyetçilik, kadınlar tarafından cinsiyetçilik ve ayrımcilık olarak algılanmamaktadır (Barreto ve Ellemers, 2005; Becker ve Swim, 2012; Swim ve ark., 2005). Benzer şekilde, kadınlar, korumacı cinsiyetçilik ile açıklanan erkek davranışlarına da karşı fazla tepki vermemektedir (Moya ve ark., 2007). Ayrica, korumacı cinsiyetçilik düzeyi yüksek olan kadınlar, kadınlara yapılan ayrımcılıkları meşrulaştırmaktadır. Korumacı cinsiyetçilik arttıkça, kadınlar, düşmanca cinsiyetçiliğe de olumlu yaklaşmaktadır (Sibley ve ark., 2007). Kısacası, korumacı ve düşmanca cinsiyetçiliği benimseyen kadınların, toplumsal cinsiyet eșitsizliğine tepki vermede oldukça pasif kaldıkları söylenebilir.

Cinsiyetçiliğin korumacı boyutu, cinsiyet eşitsizliğini meşrulaştıran bir yöndür (Jost ve Kay, 2005; Sibley ve ark., 2007). Bu açıdan Sistemi Meşrulaştırma Kura$m \imath$ 'nı da ele almakta fayda vardır. Jost ve Kay (2005) var olan cinsiyet sistemini meşrulaştıran kadınların, sosyal hiyerarşide erkeklerin üstün pozisyonlarını kabul ettiklerini belirtmektedir. Sistemi Meşrulaştırma Kuramı'na göre, dezavantajlı konumdaki grupların (örn., kadınlar) üyeleri benlik saygıları ve grup kimliklerine rağmen gruplar arasındaki eşitsizliği meşrulaştırmaktadır. Bireyler, cinsiyet sosyalleşmeleri sırasında sistemi meşrulaştıran tutumlar geliştirmektedir. Var olan sistemleri adil, doğal ve kaçınılmaz olarak algılayarak, gruplarının toplumsal hiyerarşideki yerini hak edilmiş olarak görmektedirler. Toplumsal cinsiyet kalıpyargılarını da sistemi meşrulaştırmada kullanmaktadırlar (Jost ve Banaji, 1994; Jost ve Kay, 2005). Bilindiği gibi, birçok toplumda kadınlar toplulukçu ve diğerleri odaklı; erkekler ise kendi odaklı ve yetkin olma kalıpyargılarılla tanımlanmaktadır. İki cinsiyete atfedilen bu kalıpyargılar, cinsiyetlerin birbirlerinin tamamlayıcısı olduğu algısını yaratmaktadır. Kadınlara atfedilen tamamlayıcı cinsiyet kalıpyargıları (örneğin, kibar, yardımsever, sevecen, empati kuran şeklindeki kadınlara atfedilen olumlu kalıpyarg1lar), erkeklere atfedilen yetkin ve yarışmacı özelliklere sahip olamayacakları algısını beraberinde getirmektedir. Bunun sonucunda, toplumsal cinsiyet eşitsizliği içselleştirilmekte ve hem kadınlar hem de erkekler var olan cinsiyet sistemini geçerli görüp, karşı çıkmamaktadır (Jost ve Kay, 2005; Laurin ve ark., 2011). Yapılan çalışmalara göre, cinsiyet sistemini meşrulaştıranlar, feminist görüşlere karşı çıkmaktadır (Yeung ve ark., 2014). Yine, performans değerlendirmesi yapan kadın katılımcılar, kendilerinin katkılarını erkeklerinkinden daha değersiz algılamaktadır (Jost, 1997). Bu bulgular da kadınların, cinsiyetçiliği kabullendiklerini ve meşrulaştırdıklarını gösterir niteliktedir.

Çelişik duygulu cinsiyetçiliğin ve sistemi meşrulaştırmanın yanı sıra, toplumsal cinsiyet eşitsizliğinin pasif bir şekilde kabullenilmesini ve meşrulaştırılmasını sağlayan diğer bir değişken de sağ kanat yetkecilik olabilir. Kendilerinden farklı olan azınlıkları geleneksel değerlerine tehdit olarak algılama eğiliminde olan sağ kanat yetkeci bireylerin, toplumda otorite figürlerine boyun eğdikleri; dindar, geleneksel-muhafazakar oldukları ve kendi dünya görüşlerini savunma güdüsüyle azınlık konumdaki gruplara önyargılı oldukları bilinmektedir (Altemeyer, 1998). Bu bilgiye göre, sağ kanat yetkecilikte yüksek olan kadınlar, geleneksel cinsiyet rollerini ve kalıpyargılarını geleneksel ana değerler olarak benimseyerek cinsiyetçiliği olumsuz algılamayabilir. Kendilerinin de savunduğu bu değerlere uygun olarak cinsiyetçi tavır ve davranışlara ses çıkarmayıp, bu değerlerle uyumlu bir biçimde yaşamaya devam edebilirler. $\mathrm{Bu}$ önermelere uygun bir şekilde, Haddock ve Zanna (1994) tarafından yapılan bir araştırmada, sağ kanat yetkecilikte yüksek olan kadınlar, feministler ile kendileri arasındaki farkların çok fazla olduğunu belirtmiş ve ev kadınlarına oranla feministlere ilişkin daha olumsuz tutumlar sergilemiştir.

Benzer bir şekilde, Sosyal Baskinlık Kuramı (Pratto ve ark., 2006; Sidanius ve ark., 2000) toplumlarnn grup temelli hiyerarşilerde üç sisteme sahip olduğunu ve bu sistemlerden birinin de cinsiyet sistemi olduğunu belirtmektedir. Cinsiyetçilik yazınına paralel olarak, ele alınan bu cinsiyet sisteminde, erkeklerin kadınlar üzerinde sosyal, politik, ekonomik ve askeri gücü olmasına ve kadınların erkekler tarafindan kontrol edilmesine odaklanılmaktadır. Pratto ve arkadaşlarına (2006) göre, cinsiyetçilik ve kalıpyargılar grup temelli hiyerarşiyi arttıran ve meşrulaştıran mitlerdir. Bu durum, içlerinde Türkiye'nin de bulunduğu 57 ülkede (Dünya Değerler Anketi kullanılarak) incelenmiş ve cinsiyetçi ideolojilerin toplumlarda cinsiyet eşitsizliğini yarattığı, $\operatorname{arttırdığ~} 1$ ve durumu daha da kötüleştirdiği bulunmuştur (Brandt, 2012). $\mathrm{Bu}$ açıdan sosyal baskınlık yönelimi yüksek olan bireylerin, cinsiyetçi sisteme uygun davranışlar sergilemeleri ve erkekleri üstün görüp, kadın-erkek eşitsizliğinin adil ve doğru olduğunu düşünerek cinsiyetçi sistemi desteklemesi mümkündür (Pratto ve ark., 1994). Bu bulguları destekler nitelikte Türkiye'de yapılan yeni bir çalışmada da (Kaynak-Malatyalı ve ark., 2017) sosyal baskınlık yöneliminde yüksek olmak, kız çocuklarının evlendirilmesine ilişkin tutumları olumlu yönde yordamıştır. 
Görüldüğü üzere, kadınlar, cinsiyetçilik düzeyleri, sistemi meşrulaştırma eğilimleri, sağ kanat yetkecilik düzeyleri ve sosyal baskınlık yönelimleri gibi farklı nedenlerle cinsiyetçiliğin farkına varmayabilir. Yaşadıklarını olması gereken ve geçerli sosyal kurallar bütünü olarak algılayıp, cinsiyetçiliğin varlığını algılamayabilirler. Buna karşın, belirli bir aşamadan sonra kadınların cinsiyetçilik farkındalıkları oluşabilir veya artabilir, ancak bu durumda da yine pasif bir şekilde suskun kalarak toplumsal kurallara uyabilirler. Bundan sonraki alt başlıkta alanyazında kadınların kendini suskunlaştırması olarak ele alınan konular sunulacaktır.

\section{Kendini Suskunlaştırma}

Cinsiyetçilik farkındalığg olan ya da farkındalığı artan kadınların bazıları, cinsiyetçi davranışlara karşı olsalar ve içlerinde olumsuz duygular yaşasalar bile yine de toplumsal kuralların etkisiyle harekete geçemeyip sessiz kalmayı tercih edebilir. Örneğin, Swim ve Hyers'ın (1999) laboratuvar ortamında yaptıkları bir çalışmada kadın üniversite öğrencileri bir grup tartışması esnasında cinsiyetçi şakalara maruz bırakılmıştır. Bu kadın katılımcıların \%55'i grup tartışması esnasında cinsiyetçi şakalara hiç yorum yapmamıştır. Ancak, doldurdukları ölçeklerinde şaka yapan kişiyi cinsiyetçi olarak değerlendirme oran1 $\% 75$ ve cinsiyetçi kişi hakkında olumsuz düşünce ve duygulara sahip olma oran $1 \% 91$ olarak bulunmuştur. Benzer şekilde, Woodzicka ve LaFrance (2001) ise laboratuvarda görüşme içeren çalışmalarında, kadınların cinsel içerikli sorular soran erkek görüşmeciyle yüzleşme oranının çok düşük olduğunu bulmuştur.

Araştırmacılara (Jack, 1991; Jack ve Drill, 1992) göre, cinsiyet eşitsizliği içeren geleneksel roller, kadınlara erkeklerin ihtiyaçlarının kadınlarınkinden daha önemli olduğunu ve iyi bir kadının diğerlerinin ihtiyaçlarını kendi ihtiyaçlarının önüne koyup, kendi duygu ve düşüncelerini gizlemesi gerektiğini vurgulamaktadır. Birçok toplumda, kadınlardan, aile ve yakın ilişkilerine kendilerini adamları, fedakârlıkta bulunmaları, diğerlerini memnun etmeleri ve olası olumsuz hislerini bastırmaları beklenmektedir. Bu tür geleneksel sosyal kuralları ve cinsiyet kalıpyargılarını içselleştiren kadınlar, yakın ilişkilerinde sorun çıkarmamak ve düzeni korumak ad1na kendilerini suskunlaştırabilir (Hurst ve Beesley, 2013; Jack, 1991). Geleneksel cinsiyet rollerini ve buyurgan kalıpyargıları benimseyen kadınlar, ilişkinin sonlanmasından korkma, misilleme beklentisi, kötü hissetme ve enerjilerini boşa harcama hissiyatı gibi nedenlerle cinsiyetçiliğe sessiz kalabilmektedir. Çatışmadan kaçınma arzuları ile isteklerini ve sorunlarını dile getirmemektedirler (Hyers, 2007). Bu duruma kendini suskunlaştırma (kendini sessizleştirme, kendini susturma, benliği susturma veya benliği suskunlaştırma şeklinde de ifade edilebilir; self-silencing) denilmektedir (Jack, 1991). Swim ve ark. (2010) bir şeyler söylemek istemeye rağmen söylememeyi de kendini suskunlaştırma olarak ele almaktadır. Diğer bir deyişle, kendini suskunlaştırma, bir ilişkiyi devam ettirmek ve korumak adına kadınların cinsiyetçi tavır ve davranışlara karşı içlerinde yaşadıkları duygu, düşünce ve davranış isteklerini bastırmalarını ve kendilerini susturmalarını içeren bir ilişki stratejisi olarak tanımlanmıştır (Jack, 1991). Her kültürde cinsiyetçi tutumlar ve davranışlar karşısında nasıl davranılması gerektiğine dair açık veya gizil sosyal kurallar mevcuttur. Kadınlar kendilerini ve ilişkilerini korumak adına bu tür kendini suskunlaştırma stratejilerini kullanmayı öğrenir. Bir açıdan kadınlar, cinsiyetçilik dolayısıyla içlerinde yaşadıkları rahatsızlığı, kızgınlığı ve çı̆̆lığı sessizleştirmek durumunda kalır. Bu tür bir uyma stratejisini kullanmak kimliklerinin ve benliklerinin belirli bir bölümünü saklamaları anlamına gelir (Jack, 1991; Jack ve Dill, 1992).

Klinik açıdan depresyon geçiren kadınlarla yaptıkları çalışmaları sonucunda Jack ve arkadaşları (Jack, 1991; Jack ve Dill, 1992) dört alt faktörden oluşan Kendini Suskunlaştırma Ölçeği'ni geliştirmişlerdir. Bu ölçekte Kendini Dış Standartlarla Değerlendirme faktörü, kadınların kendilerini içsel standartlar yerine dişsal standartlarla değerlendirmelerini kapsamaktadır. Çatışmadan Kaçınma faktörü, kadınların ilişkilerinde sorun yaşamamak ve çatışmadan kaçınmak adına kendi duygu ve düşüncelerini dışarı yansıtmamalarını ve kendilerini ifade etmemelerini içermektedir. Kendini Feda Ederek Diğerlerine Bakma faktörü ise diğerlerinin düşünce ve ihtiyaçlarını kendi düşünce ve ihtiyaçlarının önüne koyma (fedakârlık) eğilimidir. Bölünmüş Benlik (depresyon ile ilintili olarak) faktörü, kadınların içlerinde büyüyen kızgınlığı ve düşmanlığı göz ardı ederek kendilerini geleneksel kadın rollerine uygun bir şekilde sunmalarıdır. $\mathrm{Bu}$ ölçeğin depresyonun dinamiklerini ölçtüğü belirtilmiştir (Jack ve Dill, 1992). Bu ölçek, depresyon geçiren kadınlarla yapılan çalışmalar sonucunda geliştirildiği göz önünde bulundurularak çalışmalarda kullanılmalıdır.

İlgili alanyazına dayanarak, farklı unsurların kadınların kendini suskunlaştırması ile ilintili olduğu söylenebilir. Kadınlar, karşısındakini ayrımcı ve kötü olarak nitelendirmemek adına kendilerine yapılan cinsiyetçi tavırlara ve davranışlara suskun kalabilir (Crosby, 1984). Suskunluklarını bırakarak, davranış değişikliği yaratabileceklerine dair inancı kendilerinde bulamayabilirler. Öz yeterlikleri düşük olan kişilerin davranış değişikliği göstermelerinin zor olduğu bilinmektedir (Bandura, 1977). Dolayısıyla bu kişilerin bilişsel olarak bir şeyler yaparak değişim yaratma motivasyonları olmayabilir. Kadınlar da suskunluk yerine yapacakları farklı bir davranışın toplumdaki cinsiyetçiliğgi değiştiremeyeceğini düşüne- 
bilir. $\mathrm{Bu}$ beklentilerin yanı sıra gerekli davranışları yapabilecek yetenek veya becerileri kendilerinde göremeyebilirler. Öz yeterlik ve motivasyon unsurlarının yanı sıra yakın ilişkinin kalitesi de kendini suskunlaştırmayı etkileyebilir. Örneğin, evli çiftler çatışma yaşadıklarında kendilerini daha fazla suskunlaştırmıştır (Whiffen ve ark., 2007). Günlük yaşamda cinsiyetçi tutumlara sahip olma ve cinsiyetçiliğe maruz kalma da kendini suskunlaştırmaya neden olabilir. Araştırmalara göre, geleneksel cinsiyetçi tutumları benimseyen kadınlar yakın ilişkilerinde kendilerini suskunlaştırırken, toplumsal cinsiyet eşitliğini destekleyen kadınlar kendilerini daha az suskunlaştırmıştır (Witte ve Sherman, 2002). Yakın zamanda cinsiyetçi deneyimler yaşama ve geleneksel kadınsı cinsiyet rollerini benimseme kendini suskunlaştırmayı anlamlı düzeyde yordamıştır; buna karşın, feminist düşüncelere sahip olma ve sosyal değişime bağl1lık kendini suskunlaştırmayı azaltıcı etki göstermiştir (Watson ve Grotewiel, 2016). Ayrıca, cinsel nesne olarak görülme deneyimleri fazla olan kadınların bu durumları görmezden gelip, sessiz bir şekilde hayatlarına devam ettikleri de bulunmuştur (Fairchild ve Rudman, 2008; Watson ve ark., 2012).

Kendini suskunlaştırmayla ilintili olarak ele alınabilecek diğer bir sosyal psikolojik kavram reddedilme hassasiyeti (rejection sensitivity) olabilir. Reddedilme Hassasiyeti Modeli, bireylerin, değer verdikleri kişiler tarafından reddedilebilme olasığı ile ilgilenmelerini ve bu durumun onların iyi oluş hallerini ve ilişkilerini etkilemesini ele almaktadır (Downey ve Feldman, 1996; London ve ark., 2007; London ve ark., 2012). Bu modele göre, reddedilme olasılığını algilayan ve bunun bir bedeli olacağı beklentisi içinde olan kişiler, kendilerini bu reddedilmeden korumaya çalışır. Özellikle kendilerinden daha güçlü kişilere bağımlı iseler kendilerini kabul ettirebilmek ya da ilişkilerini korumak adına reddedileceklerini düşündükleri konu hakkında suskunluğu tercih ederler (Eagly ve Chrvala, 1986). Reddedilme hassasiyeti nedeniyle kadınlar, aile, akademi ve iş ortamlarında kendini suskunlaştırma stratejisini kullanabilir. Örneğin, London ve arkadaşları (2012) karizma, girişkenlik ve performans gibi erkek kalıpyargıları ile ilgili durumların kadınlarda reddedilme hassasiyetini etkinleştirebileceğini ve bu etkinleşmeden dolayı reddedilmemek için kadınların suskunlaştıklarını ileri sürmüşlerdir. Akademik ortam ele alınarak yapılan bu çalışmada, cinsiyetlerinden dolayı reddedilebileceklerini düşünen kadınlar, bu tür reddedilme tehdidi algısıyla kendilerini suskunlaştırmiştır.

Kendini suskunlaştırmanın görüldüğü diğer bir durum ise kadınların yardıma ihtiyaçları olduğu halde yardım istememeleridir (Wakefield ve ark., 2012). Sözü edilen araştırmacılar, kendi cinsiyetleri ile ilgili kalıpyar- gıları doğrulayacağını düşündükleri durumlarda kadınların yardım istemekten kaçınacaklarını ileri sürmüştür. Bu çalışmada, araştırmacılar, katılımcıların bağımlılıkla ilgili kalıpyargılar hakkındaki farkındalık düzeyini manipüle ederek, yardım arama davranışlarını incelemişlerdir. Söz konusu araştırmada, bağımlılık kalıpyargısı farkındalığının arttırıldığı koşulda bulunan hem kadın hem de erkek katılımcıların yardım arama düzeyleri düşmüştür. Bu bilgi 1şığında, eğitim, sağlık ve psikolojik danışma gibi konularda cinsiyetlerinden dolayı bağımlı algılanmamak adına kadınların kendilerini suskunlaştırabilecekleri ve yardım istemeyebilecekleri belirtilebilir. Bu yüzden de kadınlar, biraz yardım alarak yapabilecekleri şeyleri yapamaz hale gelebilir ve başarısız olabilir.

Üstte belirtilen bulgular ve öneriler ışığında, geleneksel olarak, Türkiye'de kadınların kendilerine yapılan haksızlıklara ve cinsiyetçi davranışlara sessiz kalmalarının, alttan almalarının ve karşılık vermemelerinin beklendiği söylenebilir. Sakall1-Uğurlu ve arkadaşlarının (Sakall1-Uğurlu ve ark., 2018; Sakall1-Uğurlu ve ark., 2021) çalışmaları bu önermeyi doğrular niteliktedir. Bu çalışmalar kadınların, fedakâr, özverili, sabırlı, anlayış1, affedici ve düşünceli sıfatlarıyla tanımlandıklarını göstermiştir. Buna ek olarak, Türkiye'deki öğretiler de kendini suskunlaştırmayı destekliyor olabilir. Örneğin, Türkiye'deki “büyüğe saygılı ol, karşı çıkma (sessiz kal)" öğretisi ile ifade edilmeye çalışılan yaş atfının yanı sıra önemsenme ve üstünlük atıfları da içeriyor olabilir. Toplumsal cinsiyet açısından, "büyük" olan veya üstün görünen kişi “erkek” olarak algılanabilir. Kadınların erkekler karşısında suskun kalmaları öğretisi bir sosyal kural şeklinde işleyebilir. Yakın ilişkilerinde, özellikle de evlilikte, kadınların kocalarına karşı gelmemeleri ve olumsuz eleştirilerde bulunmamaları gerektiği algısını oluşturabilir. Bu tür geleneksel normların sunulmasının nedeni, bu tutum ve davaranışların erkekler tarafından erkekliğe tehdit olarak algılanabilir olmasıdır (erkeklik ile ilgili tarama yazısı için bkz. Sakallı ve Türkoğlu, 2019). Toplumsal cinsiyet rollerinin ve erkeklik algis1nın baskısıyla kadınlar ilişkilerini devam ettirmek adına fedakârlıkta bulunmak zorunda olduklarını hissedebilir. Ayrıca, namus kültürü olarak kabul edilen Türkiye'de kadınların geleneksel buyurgan kalıpyargılara uymamas1 utanç ve aşağılanma duyguları ile sonuçlanabilir (bkz. Sakall1-Uğurlu ve Akbaş, 2013). Bu tür buyurgan sosyal kurallara uymamak, kadınların karşılaşabilecekleri yaptırımlardan (örn., eşin psikolojik veya fiziksel şiddet uygulaması; ailenin ona küsmesi veya dışlaması) korkmalarına neden olabilir. Bu tür duygu ve korkulardan dolayı kadınlar, vermek istedikleri tepkileri veremeyebilir ve kendilerini suskunlaştırabilir. Bu tür konuların Türkiye'de araştırılması kendini suskunlaştırma yazınına büyük katkı sağlayacaktır. 
Sonuç olarak, kadınların bir kısmı bir ölçüde cinsiyetçiliğin farkına varsalar da toplumsal kuralların etkisiyle kendilerini suskunlaştırabilir. Ancak, cinsiyetçi yaşantılar, bireysel farklılıklar ya da diğer sosyal psikolojik etkenler sonucunda bazı durumlarda suskunluklarını bozup cinsiyetçilik ile yüzleşme ihtimalleri de olabilir. Bir sonraki alt başlık altında bu tür aktif yüzleşme davranışlarını ele alan çalışmalara yer verilecektir.

\section{Cinsiyetçilikle Yüzleşme}

Cinsiyetçilik farkındalığı yüksek olan kadınların bir kısmı bireysel olarak cinsiyetçi tutumlara ve davranışlara doğrudan karşı koymaya çalışabilir. Günlük yaşamlarında cinsiyetçi tavırlara ve davranışlara karşı daha sözel ve sorgulayan tepkiler gösterebilir, yani cinsiyetçilikle yüzleşebilir. Cinsiyetçi davranışlar gösteren kişiye bu davranışların olumsuz algılandığını ve onaylanmadığını doğrudan ifade etmeye cinsiyetçiliğe karşı çıkma ya da cinsiyetçilikle yüzleşme (confrontation) denilmektedir (Kaiser ve Miller, 2004; Shelton ve Stewart, 2004). Cinsiyetçilikle yüzleșme, stresli bir durum ile başa çıkma yollarından biri olarak ele alınmış ve bu tür tepkilerin, cinsiyetçiliğin hedefi olma durumunu değiştirme çabasını içerdiği belirtilmiştir (Kaiser ve Miller, 2004). Araştırmacılar, sözel yüzleşmelerde cinsiyetçi tavirlar gösteren kișinin sorgulanabileceğini (örn., "neden böyle yapıyorsun?") ve cinsiyetçi tavırları göstermemesi gerektiği konusunda bilgilendirilebileceğini önermektedir. Cinsiyetçilikle yüzleşmede, genellikle, sözel olarak doğrudan karşı çıkma ele alınsa bile göz devirme, başı yanlara sallayarak eleştirme, şaşkınlık, espri yapma, alaya alma, iğneleme ve iğrenme gibi sözel olmayan ve vücut dili kullanılarak verilen tepkiler de bu kapsamda ele alınmaktadır (Ashburn-Nardo ve ark., 2008; Hyers, 2007; Swim ve Hyers, 1999).

Alanyazın incelendiğinde, cinsiyetçilikle yüzleşebilmek için farkındalığın önemli olduğu görülmektedir. Araştırmacılara (Ashburn-Nardo ve ark., 2008; Strangor ve ark., 2003) göre, cinsiyetçilikle yüzleşebilmesi için bireyin karşılaştı̆̆ tavır ve davranışları cinsiyetçi ve ayrımc1 olarak algılaması ve yorumlaması gereklidir. Daha sonra algılanan bu cinsiyetçi tavır ve davranışlara karşı hemen bir şey yapılması gerektiğinin düşünülmesi, sorumluluğun alınması, nasıl karşılık verileceğine karar verilmesi ve cinsiyetçiliğe karşı çıkılması söz konusudur. Kısacası, cinsiyetçilikle yüzleşmenin oluşabilmesi için kadınların, erkek tutumlarına ve davranışlarına önyarg1 ve ayrımcılık yüklemeleri yapmaları gereklidir.

Yukarıda belirtilen cinsiyetçiliğin farkına varma, gözlenen davranışları önyargı olarak nitelendirme ve sorumluluk alıp cinsiyetçilikle yüzleşme, kişinin kadın olma kimliği ile özdeşleşmesine (Good ve ark., 2012; Leach ve ark., 2008), kendini feminist olarak tanımla- masina (Ayres ve ark., 2009; Leaper ve Arias, 2011) ve feminist değerlere sahip olmasına bağlıdır (Hyers, 2007; Swim ve ark., 2010). Örneğin, Major ve arkadaşları (2003) kendi cinsiyetleri ile yüksek seviyede özdeşleşen kadınların (örn., "Kadın olmak, kim olduğumun önemli bir parçasıdır.") diğerlerine oranla erkek değerlendiricinin olumsuz geri bildirimlerini cinsiyetçi önyargilara daha fazla yüklediklerini bulmuştur. Benzer şekilde, Wang ve Dovidio (2017) deneysel ortamda kendi cinsiyet kimliklerine odaklanması sağlanan kadınların, cinsiyetçi yorumları algıladıklarını ve bunlara karşı koymaya çalıştıklarını göstermiştir.

Cinsiyetçilikle yüzleşme davranışları, yüzleşmeyi gerçekleştirenleri ve cinsiyetçi davranışları gösterenleri farklı şekillerde etkileyebilir. Örneğin, ilkokul öğrencileri, cinsiyetçiliğe karşı koyma egzersizi yaptıklarında cinsiyetçiliğe daha rahat bir şekilde karşı çıkmışlardır (Lamb ve ark., 2009). Benzer şekilde, etraflarındaki birinin cinsiyetçilikle yüzleştiğine şahit olan kişiler bu durumu örnek alarak benzer cevaplar vermeyi düşünmüştür (Lamb ve ark., 2009). Bunun yanı sıra, kadınların cinsiyetçi tavır ve davranışlarla yüzleşmeleri etraftaki kişilere o ortamda cinsiyetçi sosyal kuralların geçerli olmadığ ve cinsiyetçiliğin kabul edilmediği mesajını vermiştir (Dickter ve ark., 2012). Cinsiyetçi davranışların hoş karş1lanmayacağı ve kabul görmeyeceği ile ilgili mesajlar cinsiyetçilikle yüzleşmek isteyenleri de motive etmiştir (Gervais ve ark., 2010). Bu nedenlerle kamusal alanda yapılan yüzleşmeler ve cinsiyetçiliğe karşı çıkışlar, diğer insanların da cinsiyetçi davranışlara karşı gelmelerini sağlayabilmiştir (Stangor ve ark., 2001). Bu durumda da cinsiyetçi davranışları gösteren kişiler, yaptıklarının farkına vararak, cinsiyetçi davranışların kabul görmediğini, kendilerinin hatalı olduklarını algılayabilir. $\mathrm{Bu}$ kişiler, cinsiyetçi davranışların yapılmaması gerektiğini kabullenebilir ve cinsiyetçi davranışlarını azaltabilir (Hyers, 2007; Mallett ve Wagner, 2011).

Kadınların cinsiyetçilikle yüzleşmelerini farklı değişkenler etkileyebilir. İlk olarak, araştırmacılar (Swim ve ark., 2005) düşmanca cinsiyetçiliğin ve geleneksel cinsiyet rollerinin korumacı cinsiyetçiliğe ve modern cinsiyetçiliğe göre daha yüksek oranda cinsiyetçi alg1landığını göstermiştir. Bu nedenle maruz kalınan cinsiyetçiliğin türü cinsiyetçilikle yüzleşmeyi etkileyebilir. Maruz kalınan cinsiyetçiliğin türü, kadınların yaşadıklarını nasıl algılayacaklarınının yanı sıra bu konuda verecekleri kararlarını ve hareketlerini etkileyebilir. Örneğin, Ayres ve arkadaşları (2009) kadınların cinsiyetçi yorumlara kıyasla istenmeyen cinsel yaklaşımlarla daha az yüzleştiklerini bulmuştur. Kadınların adil olmayan muameleler veya arzulanmayan cinsel yaklaşımlara kar\$̧1 koyma olasılıkları, cinsiyetçi şaka ve yorumlara karş1 koyma olasılıklarına göre daha düşük bulunmuştur çün- 
kü bu tür cinsiyetçi davranışlara karşı koymak daha fazla olumsuz tepki ya da bedel (örn., işten atılma, fiziksel güvenlik endişesi/kaybı, düşük not alma) ile karşılaşmaya neden olabilmektedir (Ayres ve ark., 2009).

İkinci olarak, failin tanıdıklığl ve statüsü cinsiyetçilikle yüzleşmeyi farklı şekillerde etkileyebilmektedir (Ayres ve ark., 2009). Bu araştırmacılara göre, kadınlar, bildikleri / tanıdıkları (arkadaşları, aile üyeleri, iş arkadaşları) ve eşit statüde oldukları kişilerle daha fazla yüzleşmektedir. Tanıdıklara ve benzer statüdeki kişilere karşı koyma kadınlar açısından görece daha kolay olmuştur. Böyle durumlarda kadınlar, tanıdıkları kişilerin cinsiyetçi davranışlarına karşı koymayı daha az riskli algılamakta veya cinsiyetçi davranış hakkında neler hissettiklerini karşılarındakine ifade etmek için zaman ayırmaktadır. Tanımadıkları birinin cinsiyetçi davranışlarına karşı koyma ise bilinmezlik ve korku duygularının yanı sıra tehlike hissetmeyi de içerebilmektedir. Ayrıca, tanıdıklığın yanı sıra failin statüsü, çeşitli bağlamlarda cinsiyetçilikle yüzleşmeyi farklı şekillerde etkilemektedir. Ashburn-Nardo ve arkadaşlarının (2014) yapt1ğ1 deneysel çalışmalarda, iş yeri ortamında güce sahip birinin (örn., müdür) cinsiyetçi tavır ve davranışlarına karş1 çıkma niyetinin düştüğü bulunmuştur. Söz konusu çalışmada, algılanan sorumluluk, tepki verme kararı ve ödül-bedel algısı da ölçülmüștür. Bulgulara göre, cinsiyetçi tavırlar gösteren kişinin gücü arttıkça katılımcıların kişisel sorumluluk alma algısında ve tepki verme kararında düşme görülmüştür. Karş1lık verirlerse zarara uğrayacakları algısı artmıştır. İş yeri ortamı ele alınarak yapılan bu deneyin bulgularına paralel olarak, evlilikte ya da sosyal ortamlarda erkeğin güce sahip olduğu algılandığında, kadınların cinsiyetçi tavırlara karşı çıkma olasılıkları düşüktür. Benzer şekilde, kadınların kendilerini güçsüz görmeleri nedeniyle kendi görüş ve tutumlarını ifade etmemeleri de söz konusudur (Anderson ve Berdahl, 2002).

Ortamın özelliklerinin cinsiyetçilikle yüzleşmeye etkilerini ele alan çeşitli çalışmalar mevcuttur. $\mathrm{Bu}$ çalışmalara göre, deney veya araştırma ortamlarında cinsel taciz deneyimine verileceği söylenen tepkiler ile gerçek yaşamda verilen tepkiler farklılık göstermiştir. $\mathrm{Bu}$ araştırmalarda kadınlar olası durumlarda cinsiyetçilikle yüzleşeceklerini söyleseler bile gerçek yaşamlarında yüzleşmemişlerdir (Fitzgerald ve ark., 1995; Harris ve Firestone, 1997). Örneğin, Woodzicka ve LaFrance (2001) kadın katılımcıların \%62'sinin cinsiyetçi sorular soran erkek görüşmeciye tepki verebileceklerini ve bu tür soruların uygunsuz olduğunu söyleceklerini belirttiklerini ama sadece \%36'sının bunu gerçekten yaptıklarını bulmuştur. Benzer şekilde, Shelton ve Stewart'ın (2004) katılımcılardan hayal kurmalarını istedikleri çalıșmalarında, kadınlar, sosyal bedeli ne olursa olsun ayrımcı davranan görüşmeciyle yüzleşeceklerini söyleseler bile gerçekte yüz yüze görüşmeleri içeren çalışmalarında kadınların yüzleşme oranının düşük olduğu bulunmuştur. Ayrica, laboratuvar ortamında kadın katılımcilar cinsiyetçi durumdan rahatsız olsalar bile tepkileri farklı olmuştur. Örneğin, Swim ve Hyers (1999) laboratuvar ortamında kadınların \%16'sının doğrudan sözel olarak, \% 45 'nin de diğer yüzleşme stratejilerini kullanarak cinsiyetçi yorumlar yapan erkeklerle yüzleştiklerini bulmuştur. Kadın katılımcılar görüşme ortamında cinsel açıdan taciz içeren sorular soran erkek görüşmeciyle yüzleşmiştir. Kadınların \%91'i ise yüzleşmeseler bile durumdan rahatsız olduklarını belirtmiştir. Araştırma ortamı ve yüz yüze gerçek yaşam ortamlarının yanı sıra internet ortamı da araştırmacılar tarafından ele alınmıştır. Gervais ve arkadaşları (2010) internet üzerinden yapılan iletişimin yüzleşmeyi kolaylaştırdığını; bunun nedeninin düşük bedel algısı olduğunu belirtmiştir.

Cinsiyetçilikle yüzleşmeyi etkileyebilecek diğer bir değişken ise, yukarıda da farklı noktalarda birkaç kez belirtildiği gibi, bireylerin herhangi bir tepkide bulunmadan önce ödül-bedel hesaplamalarıdır (Kowalski, 1996). İkili ilişkilerde bedel ödeyeceğini (örn., saldırıya uğrama korkusu) düşünen kadınlar, cinsiyetçilikle yüzleşmemiştir (Shelton ve Richeson, 2005). Araştırmacılar (Sechrist ve ark., 2004; Stangor ve ark., 2002) kişiler arası sorun yaşayacağını düşünen kadınların cinsiyetçilikle yüzleşmediklerini ve suskun kaldıklarını bulmuştur. Ayrıca, bedelinin az olacağı düşünülen cinsiyetçilikle yüzleşmek, diğerlerinin önünde değil de özel olarak kişiye yapıldığında daha kolay gerçekleşmiştir. Bedel algısının yanı sıra cinsiyetçilikle yüzleşme tepkisinin cinsiyetçiliği azaltacağı beklentisi ve kişinin konu ile ilgili kaygısı da cinsiyetçilikle yüzleşme ile ilişkili bulunmuştur (Kaiser ve Miller, 2004). Bu yazarlara göre, bedelin düşük, ödülün yüksek olacağı konusunda iyimser olan kadınlar, cinsiyetçilikle yüzleşecek becerilerinin olduğunu belirtmiştir.

Cinsiyetçilikle yüzleşen kişilerin diğerleri tarafindan nasıl algılandiğı da cinsiyetçilikle yüzleşme tepkisine bariyer oluşturabilmektedir. Farklı koşullarda farklı cinsiyetçilik türü ile yüzleşen kadınların diğerleri tarafından art niyetli, olayları abartan, sorun çıkaran, soğuk, mızmızlayan ve gereğinden fazla tepki veren kişiler olarak algılandıkları görülmüştür (Becker ve ark., 2011; Czopp ve Monteith, 2003; Dodd ve ark., 2001; Kaiser ve Miller, 2003). Araştırmacılar (Dodd ve ark., 2001) cinsiyetçilik ile yüzleşen kadınların cinsiyetçilik ile yüzleşen erkeklere kıyasla daha az sevildiklerini, daha az sayg1 gördüklerini ve daha çok suçlandıklarını ileri sürmüştür. Bunun yanı sıra, cinsiyetçilikle yüzleşen kişilerin, misilleme ve aşağılanmayla karşı karşıya kalabildikleri belirtilmiştir (Fitzgerald ve ark., 1995; Kaiser ve Miller, 
2003). Örneğin, cinsel taciz hakkında suçlamada bulunan kadınların kurumları tarafından cezalandırıldıkları bulunmuştur (Bergman ve ark., 2002).

$\mathrm{Bu}$ bilgilere göre, cinsiyetçi tavırlarla ve davranışlarla yüzleşen kadınlar, erkeklere kıyasla, daha egoist ve çıkarcı algılanabilir. Tüm bu olumsuz değerlendirmeler nedeniyle kadınlar cinsiyetçilikle yüzleşmeye çekinebilir ve kendini suskunlaştırmayı tercih edebilir. Namus kültürlerinde (örn., Türkiye) bu suskunluk tercihi namus algısı ile farklı bir boyut kazanabilir. Kadınlar, karşılaştıkları cinsiyetçi tavırların sorumlusu algılanırlarsa suçlanabilecekler ve kendilerine yüklenecek bu suç ile namuslarının lekelendiği algısı oluşabilecektir (namus konusunda derleme için bkz. Sakall1-Uğurlu ve Akbaş, 2013). Bu durumda bazı kadınların suskunluğu ve yüzleşmemeyi tercih etme eğilimleri artabilecektir. K1sacası, kadınlar yaşadıkları cinsiyetçiliğin türüne göre, yapacakları davranışın namuslarını koruyucu mu yoksa zedeleyici mi olduğu algısına göre suskunluk ya da yüzleşme gibi farklı tepkiler gösterebilir. Bu bilgi ve önermeler çerçevesinde, Türkiye'de namus algısı, cinsiyetçilikle yüzleşme ve kendini suskunlaştırma konularında araştırmalar yapılması yerinde olacaktır.

Bireysel olarak cinsiyetçilikle yüzleşmenin bir sonraki aşaması ise kolektif hareket olabilir. Cinsiyetçilik ile yüzleşme bireyin kendini savunması için yaptığ bir davranış olarak ele alınabilirken, bireyin grubuna hizmet etme niyeti ile yapabileceği bir şey de olabilir. Wright'ın (2010) belirttiği gibi, birey bu tür davranışları grubuna yardım etmek ve grubunun durumunu olumlu yönde düzeltmek amacıyla yapıyorsa, bu davranışlar kolektif hareket olarak ele alınabilir. Bu açıdan, bir sonraki bölümde kadınların dezavantajlı grup statülerinin iyileştirilmesi ve sosyal eşitliği sağlamak niyetiyle katılabilecekleri kolektif hareketler konusu ele alınacaktır.

\section{Cinsiyetçiliğe Karşı Kolektif Hareketler}

Cinsiyetçilik farkındalığı olan kadınların bazıları cinsiyet eşitliğini sağlamak amacıyla kolektif hareketlere katılmayı tercih edebilir. Kolektif hareket, azınlık grupların durumlarını iyileştirmek amacıyla gerçekleştirdikleri hareketlerdir (Wright ve ark., 1990). Bu hareketler internette kampanyalara imza vermekten, yürüyüşlere katılmaya kadar birçok davranışı kapsamaktadır (Radke ve ark., 2016). Bireyler, kendilerini dezavantajlı konumda algılayıp, bu dezavantajlı durumun kendi gruplarına yapılan bir ayrımcılık olduğunu ve bunun adil olmad1ğını düşündüklerinde grup temelli bir sosyal değişimin mümkün olduğuna inanarak kolektif harekete yönelmektedir (Klandermans, 1989). Araştırmalar (örn., Watson ve Grotewiel, 2016) cinsiyetler arası eşitliğin sağlanması yönündeki sosyal değişimde kendini sorumlu hisseden ve sosyal değişime kendini adayan kadınların suskunlu- ğu tercih etmediklerini göstermiştir. Buna göre, cinsiyetçiliğe ilişkin verilen diğer bir tepki de toplumdaki cinsiyetçiliğin ve olumsuzlukların farkında olarak kolektif hareketi tercih etmektir. Becker ve Wright'a (2011) göre, özellikle düşmanca cinsiyetçilik, kadına ilişkin olumsuz tutumları içerdiğinden dolayı kadınlara herhangi bir avantaj sağlamadığı için kadınları kolektif harekete yöneltmektedir. Kadınlar, yaşanan cinsiyetçiliğin azaltılması ya da yok edilmesi amacı ile kolektif hareketlerde bulunmaktadır.

Sosyal psikoloji alanında kolektif hareketlerle ilintili olarak öne sürülen Göreli Yoksunluk Kuramı (Crosby, 1976) ve Sosyal Kimlik Kuramı (Tajfel ve Turner, 1979) gibi önemli kuramlar, kadınların kolektif hareketlerini açıklamaya katkı sağlayabilir. Crosby (1976), göreli yoksunluğu bireylerin kendilerini veya kendi gruplarını diğer kişilerle veya gruplarla karşılaştırmaları sonucunda hak ettiklerini alamadıklarını algılayarak gücenmeleri, memnun olmamaları ve kızgınlık duymaları sonucu hissettikleri bir durum olarak tanımlamaktadır. Araştırmacılar hem bireysel hem de grup temelli göreli yoksunluk hisseden kadınların daha fazla adaletsizlik algıladıklarını ve kolektif harekete daha yüksek oranda katıldıklarını bulmuştur (Foster ve Matheson, 1995). Benzer şekilde, kolektif hareket çalışmalarının bulgularına dayanarak (örn., Kelly, 1993; Klandermans, 1989; van Zomeren ve ark., 2008) kadınların kolektif hareketinin, sosyal değişimi getirebilecek güce sahip etkin bir yol olarak görülmesi; cinsiyetler arası eşitsizliğin adaletsiz olarak algılanması; bu duruma gücenme, öfke ya da kızgınlık duyma; kendi gruplarıyla özdeşleşerek olayları kontrol edip, etki ve değişim yaratabileceklerine dair güçlü hissetme (öz yeterlik) gibi özellikler içerdiği söylenebilir. Ayrıca, ödül-bedel hesaplamalarının önemine değinen çalışmalara dayanarak (örn., Klandermans, 1989), bu hesaplamaların, kadınların kolektif harekete katılımında önemli bir değişken olduğu belirtilebilir.

Sosyal Kimlik Kuramı'yla (Tajfel ve Turner, 1979) bağlantılı olarak, cinsiyetleri ile özdeşleşen kadınların cinsiyetçiliğe karşı aktif tepkiler verdikleri bulunmuştur (Leach ve ark., 2008; Wang ve Dovidio, 2017). van Zomeren ve arkadaşlarının (2008) çalışmalarından esinlenerek, cinsiyeti ile siyasallaşmış özdeşleşme düzeyi yüksek olan kadınların cinsiyet grupları arasındaki geleneksel ilişkileri meşru algılamalarının düşük olacağı ve değişim yaratabileceklerini düşündükleri için de kolektif hareket eğilimlerinin yüksek olacağı belirtilebilir. Bu durum, özellikle kendini feminist değerlerle (Kelly ve Brienlinger, 1995; van Breen ve ark., 2017) ve feminist olarak tanımlayanlarda görülmektedir (Nelson ve ark., 2008). Bunun nedenleri kendini feminist olarak tanımlayan kadınların toplumdaki cinsiyetçiliği daha kolay algılamaları (Henderson-King ve Stewart, 1997), diğer- 
lerine oranla cinsiyetçi ideolojiyi daha fazla reddetmeleri (Zucker ve Bay-Cheng, 2010), cinsiyet hiyerarşisini adaletsiz algılamaları (Liss ve Erchull, 2010) ve cinsiyet eşitsizliği ile mücadeleyi içeren kolektif hareketlere katılmalarıdır (Liss ve ark., 2004; Nelson ve ark., 2008; van Breen ve ark., 2017; Yoder ve ark., 2011; Zucker, 2004). Araştırmacılar, benliğinde feminist kimliğe sahip olma, güce karşı rahatsızlık duyma, sistemi suçlama ve kolektif olma eğilimi gibi bazı özellikleri içeren feminist özdeşleşme ve feminist bilinçliliği değişkenlerinin kadınların kolektif hareketini yordadığını bulmuştur (Duncan, 1999; Zucker, 2004).

Buna karşın, araştırmacılar, bazı kadınların "feminist" etiketini olumsuz değerlendirme ve reddetme eğiliminde olduğunu da göstermiştir (Sakall1, 2001; Yoder ve ark., 2011). Feministler, saldırgan, zorlayıcı, uyumsuz ve zor geçinilen (Beryyman-Fink ve Verderber, 1985), var olan sosyal değerleri çiğneyen (Mahalik ve ark., 2005) ve bu değerlere tehdit oluşturan kişiler olarak algılanmıştır (Cottrell ve Neuberg, 2005). Ayrıca, feministlik, kadınların diğer gruplara kıyasla ne durumda oldukların1 yansıtan politikleşmiş bir kimlik olarak görülmüştür (van Breen ve ark., 2017). Bu açılardan kendilerini feministlerden daha sevecen gören kadınlar, feministlerle özdeşleşmemiştir (Meijs ve ark., 2017). Bu bulguya paralel olarak, feministler hakkında olumsuz değerlendirmeye sahip olan kadınlar, feministler ile özdeşleşmeden kaçınmıştır (Redford ve ark., 2016; Robnett ve ark., 2012). "Feminist değilim ama kadın-erkek eşitliğini savunuyorum" tarzı ifadeler feminist olarak etiketlenmeden kaçınma davranışlarıdır. Bu tür ifadeler kadınların feminist değerlere sahip olma eğilimleri olsa da kendilerini feminist olarak tanımlamadan kaçındıklarını göstermektedir (Burn ve ark., 2000; Robnett ve ark., 2012; Zucker ve Bay-Cheng, 2010). Bazı kadınlar ise feministler hakkında olumlu değerlendirmelere sahip olsalar bile cinsiyetçiliğin kendilerini etkilemeyeceğini hissettikleri (Weis ve ark., 2018), diğer insanların feministleri eleştirdiklerini bildikleri (Ramsey ve ark., 2007) ve feministlere ilişkin olumsuz kalıpyargıların kendilerine kişisel olarak zarar vereceğini düşündükleri (Zucker ve Bay-Cheng, 2010) için feministlerle özdeşleşmeye çekinmektedir.

Feministlere ilişkin olumlu tutumların geliştirilmesi kadınların kolektif harekete katılımlarını sağlayacak önemli bir durumdur. Araştırmalara göre, feministlere ve feminist fikirlere maruz kalma feministlere ilişkin olumlu görüşleri arttırmaktadır (Nelson ve ark., 2008; Reid ve Purcell, 2004). Feministler hakkında olumlu kalıpyarg1lara sahip kadınlar da feministlerle daha rahat özdeşleşmektedir (Roy ve ark., 2007). Feminist kişilerle sosyal temasta bulunma (Liss ve ark., 2004; Reid ve Purcell, 2004), feminist bir anneye sahip olma (Nelson ve ark., 2008) ve kadın çalışmaları gibi bölümlerden ders alma
(Bargad ve Hyde, 1991; Nelson ve ark., 2008) feminist kimlik kazanımını arttırmaktadır. Ayrıca, cinsiyetçilik ve muhafazakârlık düzeyi düşük olan kişilerin kendilerini feminist olarak tanımlama olasılıkları daha yüksektir (Liss ve ark., 2001). Kendilerini feminist olarak tanımlayan kişiler, feminist olarak tanımlamayanlara ve feminist olarak etiketlenmeyi red edenlere oranla, düşmanca cinsiyetçilik ve sosyal baskınlık yönelimini daha az benimsemiştir. Buna karşın, feminist olmadıklarını belirtenlerin ise geleneksel kurallara daha fazla uydukları gözlenmiştir (Zucker ve Bay-Cheng, 2010).

Feminist gruplarla özdeşleşme kaygısının ve korkusunun yanı sıra kolektif hareketlere bariyer oluşturabilecek diğer etmenler de mevcuttur. Radke ve arkadaşlarına (2016) göre, dünyanın yarısını oluşturan kadınların diğer kadınlarla özdeşim kurması zor olabilir. Kadınlar ve feministler farkl1 alt gruplara ayrilabilir. Bu alt gruplar farklı değerlendirilebilir. Eşitlik ve sosyal değişim isteyen bazı alt gruplar, feminist olmayan kadınlar tarafından olumsuz değerlendirilebilir. Bunun yanı sıra, cinsiyet eşitliği istense bile kolektif hareketin bir yararı olmayacağı düşünülebilir (Williams ve Wittig, 1997). Radke ve arkadaşlarına (2016) göre, kadınlar ve erkekler gruplar arası ilişkiler kapsamında incelenen diğer gruplardan oldukça farklıdır. Kadınlar ailelerinde baba, oğul, oğlan kardeş ve eş gibi farklı konumlardaki erkeklerle ailevi, sosyal veya romantik ilişki içindedir. Kadınların kendi doğurdukları erkek çocukları bulunmaktadır. Bu tür olumlu sosyal temasın olduğu gruplar arası ilişkilerde kadınların erkekleri ayrı bir grup olarak algılaması ve erkekleri dışgrup olarak görmesi zordur. Hatta bazı kadınlar cinsiyetçiliği destekleyerek ve içselleştirerek kendilerine yeni bir bariyer oluşturmaktadır (Radke ve ark., 2016). Ayrica, Becker ve Wright'a (2011) göre, kolektif harekete niyetlenmeyi engelleyen diğer değişkenler korumacı cinsiyetçiliği ve sistemi meşrulaştırmayı benimsemedir. Buna karşın, düşmanca cinsiyetçiliğin var olduğu algısı, kadın olmanın dezavantajlı olduğu düşüncesi ile sistemi meşrulaştırmadan uzaklaşmayı sağlamakta ve kolektif hareket niyetini arttırmaktadır.

\section{Cinsiyetçiliğe Verilen Tepkilerin Kadınlara Olumlu veya Olumsuz Çıktıları}

Yukarıda cinsiyetçiliği meşrulaştırma, kendini suskunlaştırma, cinsiyetçilikle yüzleşme ve kolektif hareketler olarak ele alınan dört farklı tepki türü kadınlar açısından olumlu ya da olumsuz çıktıları beraberinde getirebilir. Cinsiyetçiliğe verebilecekleri tepkiler yüzünden kadınlar hem bireysel hem de grup temelli olarak bazı bedeller ya da ödüller ile karşılaşabilir. Bu alt bölümde ilk önce bireysel temelli olumlu ve olumsuz çıtılar ele alınacaktır. Daha sonra ise grup temelli olumlu ve olumsuz çıktılara değinilecektir. 


\section{Bireysel Temelli Olumlu ve Olumsuz Çıktılar}

İlk olarak, cinsiyetçiliği kabullenmeye ve meşrulaştırmaya odaklanılacak olursa, korumacı cinsiyetçiliğin ayrımcılık olarak algılanmadığı ve bu tür davranışlar gösteren erkeklere olumsuz tepki verilmediği bulunmuştur (Barreto ve Ellemers, 2005; Becker ve Swim, 2012; Swim ve ark., 2005). Korumacı cinsiyetçiliğin olumlu tonu nedeniyle, cinsiyetçi sistemi meşrulaş̧ıran kadınların meşrulaş̧ırmayanlara oranla hayattan doyum düzeylerinin daha yüksek olduğu görülmektedir (Hammond ve Sibley, 2011; Napier ve ark., 2010). Korumacı cinsiyetçiliğin benimsenmesi ile yaşam doyumu arasındaki olumlu ilişki farklı ülkeleri içeren araştırmalarda da bulunmuştur (Napier ve ark., 2010).

Her ne kadar korumacı cinsiyetçilik ile yaşam doyumu arasında olumlu ilişsi bulunsa bile, çalışmalar korumacı cinsiyetçiliğin kadınların kendilerinden şüphe etmelerine ve kendilerini yetersiz görmelerine neden olduğunu (Dardenne ve ark., 2007; Dumont ve ark., 2010), kendilerini nesne olarak algılamaya (benlik nesneleştirilmesi) ittiğini (Calogero ve Jost, 2011) ve benliklerini nesneleștiren kadınların da kendilerini görünümlerine göre değerlendirdiklerini bulmuştur (Szymanski ve ark., 2009). Cinsiyetçiliği meşrulaştıran kadınlar, bunun gibi psikolojik süreçler, çevrelerindeki diğer cinsiyetçi davranışlar ve baskılar nedeniyle sosyal ilişki, romantik ilișki, eğitim, ekonomik pozisyon ve kariyer gibi fark11 alanlarda ayrımcılığa uğramaktadır (Glick ve Fiske, 1996; Jost ve Banaji, 1994).

Toplumsal cinsiyet rolleri ve kalıpyargılar kadınların fedakâr, cefakâr, sabırlı ve kendini ailesine adamıș olduğunu ve olması gerektiğini vurgular niteliktedir (örn., Sakall1-Uğurlu ve ark., 2018). Bu durum özellikle evli kadınlar için söz konusudur (Sakall1-Uğurlu ve ark., 2021). Toplumsal cinsiyet rollerinin gereği olarak, fedakârlıkta bulunmaları beklenen kadınlar bu rollere uyarlarsa yakın ilişkilerinde ödüllendirilebilir ve olumlu geri bildirimler alabilir. Yakın ilişkiler alanında yapılan araştırmalara göre, fedakârlıkta bulunma yakın ilişkileri olumlu yönde etkilemektedir. Fedakârlıkta bulunulduğunu gören partnerin güveni artmakta ve bunun paralelinde ilişkiye bağll1ık da artmaktadır (van Lange ve ark., 1997). Bu açıdan, toplumsal cinsiyet rollerini benimseyen kadınlar, bu fedakârlığın kendileri için olumlu dönütlere sahip olduğunu düşünebilir. Buna karşın, ne ölçüde cinsiyetçiliği benimserlerse benimsesinler, kadınların bu kadar çok fedakârlıkta bulunmasının onları olumsuz etkileyebileceğini gösteren bulgular da mevcuttur. Bu bulgulara göre, fedakârlık yapan kadınlar, bağımlılık, suçluluk, içerleme veya gücenme hissetmektedir (Rusbult ve van Lange, 1996). Kadınlar bu tür olumsuz duygular hissetmediklerini söyleseler bile, çatışmadan kaçınmak için gerçek duygularını içlerinde saklamaları zaman içerisinde ilişki memnuniyetini olumsuz olarak etkilemektedir (Canary ve Cupach, 1988; bkz. Impett ve ark., 2005). Kendini suskunlaştırma kısmında ele alındığ gibi, duyguları ifade etmeme/edememe depresyonla sonuçlanmaktadır (Jack ve Dill, 1992). Benzer şekilde, Türkiye'de yapılan bir çalışmanın bulgularına göre, kadınların Bem'in Cinsiyet Rolü Envanteri'nden elde ettikleri kadınsılık puanları arttıkça ve eğitim düzeyleri düştükçe, depresyon düzeyleri de artmaktadır (Dökmen, 2000).

Ek olarak, cinsiyet sistemini meşrulaştıran kadınlar, cinsiyetçi yaşantılar sonucunda daha fazla psikolojik rahatsızlık belirtileri göstermektedir. Örneğin, Moradi ve Subich (2002) geleneksel cinsiyet rollerini yüksek düzeyde onaylayan kadınlarda, yakın zamanda yaşanan cinsiyetçi yaşantı ile psikolojik rahatsızlık hissetme arasında, diğerlerine oranla, daha yüksek bir korelasyon bulmuşlardır. Diğer bir çalışmada, korumacı cinsiyetçiliğe maruz kalan kadınların, kendi fiziksel görünümlerine daha fazla dikkat edip diğerlerinin ve özellikle erkeklerin onayını alma gayretinde oldukları bulunmuştur. Bu tür bir durumda, kadınlar cinsiyet sistemini meşrulaştırmaktadır. Kendilerini nesneleștirerek, görünümleri ve vücut şekilleri ile ilgili davranışlarla daha fazla ilgilenmekte ve cinsiyetçi davranışlar göstermektedirler (Calogero ve Jost, 2011; Szymanski ve ark., 2009).

Geleneksel toplumsal cinsiyet ideolojilerini benimseyen kadınlar, cinsel hayatlarında da sorunlar yaşamaktadır. Geleneksel toplumsal cinsiyet kuralları, kadın ve erkeklerin ne tür cinsel davranışlarda bulunmaları gerektiğini ve karşı cinsiyete nasıl yaklaşacaklarını belirlediğinden, kadınların cinsel memnuniyet algısını ve yaşadıkları sorunları etkilemektedir. Kadınların cinsiyetçiliği pasif bir şekilde kabullenmeleri, onların cinsel girişkenlik gösterememeleri (Yoder ve ark., 2007), kondom kullanmayı talep edememeleri (Impett ve ark., 2006) ve daha fazla haz almak için cinsel arzuların dile getirmede zorlanmaları (Sanchez ve ark., 2005) gibi davranışlarla sonuçlanmaktadır.

Cinsiyetçiliğin algılanması birçok sağlık sorunu ve sağlığa zararlı davranış ile ilişkili bulunmuştur. Değersiz görülme ve ayrımcılık, kadınların yaşadıkları psikolojik sorunların nedenlerindendir (Dambrun, 2007; Klonoff ve ark., 2000). Bir yıl içinde veya tüm hayatları boyunca yaşanan cinsiyetçi davranışlar, kadınlarda anksiyete, obsesif-kompulsif rahatsizlıklar ve stres ile ilintili bulunmuştur (Landrine ve ark., 1995). Araştırmacılar, hipertansiyon (Krieger, 1990), regl semptomları (Landrine ve ark., 1995), baş ağrısı (Goldenhar ve ark., 1998), yeme sorunları ve bozukluğu (Sabik ve Tylka, 2006), sigara içme (Zucker ve Landry, 2007), zayıf olma (Heinberg ve ark., 1995), kilo kontrolü ve zayıflamak için sigara içme (Zucker ve Landry, 2007) gibi çeşitli sorunların cinsiyetçilikle ilintili olduğunu bulmuştur. 
Benzer şekilde, kendini suskunlaştırma durumunda da kadınlar bazı psikolojik sağlık sorunları yaşamaktadır. Bu sorunlardan en başta geleni depresyondur. Ergenlikten sonra kadınlar erkeklerden daha yüksek oranda depresyon (Nolen-Hoeksema, 2001) ve anksiyete (Eriksen ve Kress, 2008) yaşamaktadır. Daha önce belirtildiği gibi, klinik açıdan depresyon tanısı alan kadınlarla çalışan Jack (1991) kadınların geliştirdikleri bilişsel şemalarla yakın ilişkilerinde nasıl güvende olacaklarını bildiklerini belirtmiştir. Bu bilişsel şemalardan biri de bazı duygu, düşünce ve davranışlarını susturmaktır. Bu suskunluk, kadınların toplum tarafından buyurgan kalipyargilar ve sosyal rollere itaat etmeleri ile alakalıdır. Baskılanan kadınların kendilerini suskunlaştırma davranışları benlik saygılarının düşmesine ve depresyon yaşamalarına yol açabilmektedir. Kendilerine yapılan ayrımcılık (örn., devamlı takip, cinsel taciz) olaylarını görmezden gelip, sessiz kalan kadınlar, kendilerini suçlamakta (Fairchild ve Rudman, 2008), depresyon yaşama olasılıkları erkeklere göre daha fazla olmakta (Cramer ve ark., 2005) stres, hayata ilgisizlik ve kendinden hoşnut olmama gibi psikolojik sorunlar yaşamaktadır (Hurst ve Beesley, 2013).

Bunların yanı sıra, kadının nesneleştirilmesi çalışmalarına göre, kadının vücudu izlenilecek bir nesne olarak görülmekte ve kadın, vücuduna göre değerlendirilmektedir. Bu tür bir nesneleştirmenin kadınlar tarafından kabul edilip, içselleştirilmesi, kendini suskunlaştırmayla birlikte kadınların sürekli vücutları ile ilgilenmelerine ve yeme sorunları gibi sağlık sorunları yaşamalarına neden olabilmektedir (bkz. Maji ve Dixit, 2019). Kendini suskunlaştırma, cinsel deneyim ve cinsel hastalıklar ile ilgili sorunlar da oluşturmaktadır. Kadınlar, romantik açıdan sevdikleri erkeklerin cinsel ilişki isteklerini her durumda karşılamak zorunda hissetmekte ve partnerleri ile fantazileri-tercihleri gibi cinsel konularda konuşamamaktadır (Widman ve ark., 2006). Sorun çıkarmamak adına partnerlerinin cinsel ilişki sırasında kondom kullanmama isteklerine boyun eğmektedirler (Teitelman ve ark., 2011). Bu durumlar ise hem psikolojik hem de fiziksel sağlık sorunlar yaşamalarına yol açmaktadır (bkz., Maji ve Dixit, 2019).

Sağlık problemleri ve cinsel sorunların yanı sıra kendini suskunlaştırma kadınların akademik başarılarını da etkilemektedir. London ve arkadaşlarının (2012) belirttiği gibi, cinsiyetlerinden dolayı reddedilme olas1lıklarının yüksek olduğunu düşünen kadınlar, kendilerini suskunlaştırmakta ve bu kadınların bir üst akademik pozisyona başvurma motivasyonları düşmektedir. Bu da onların akademik hayatında ve iş hayatında ilerleme olasilıklarına zarar vermektedir.

Cinsiyetçilikle yüzleşme açısından bakıldığında, cinsiyetçi tavırlarda bulunan kişiyle yüzleșen kadınlar, farkındalık yarattıklarını, tutumları ve davranışları değiştirdiklerini hissedebilir ya da bu tepkilerinden dolayı kendileriyle gurur duyup, içsel rahatlık yaşayabilir. Dolayısıyla da benlik saygısı, yetkinlik algısı ve kendini güçlü hissetme duyguları artabilir. Hyers'ın (2007) çalışmasında, sözel veya beden dili ile doğrudan cinsiyetçilikle yüzleşen kadınlar, yaptıklarından dolayı daha memnun olduklarını; buna karşın espriye vuran, gülen ya da hiçbir şey yapmayan kadınlar, gelecekte daha farklı davranmak istediklerini ve daha fazla pişmanlık ve kızgınlık hissettiklerini belirtmiştir. Kısaca, cinsiyetçilikle yüzleşme kadınların, kendilerini iyi hissetmeleriyle ve güçlenmeleriyle ilişkili bulunmuştur (Gervais ve ark., 2010). Cinsiyetçiliğe karşı çıkan kişiler kontrolü ele aldıklarını düşünüp, memnuniyet duygusu yaşamaktadır (Hyers, 2007). Ayrıca, cinsiyetçilikle yüzleşen kişi, diğerleri tarafından da yetkin algılanmaktadır (Becker ve ark., 2011). Diğer bir açıdan bakıldığında, cinsiyetçilikle yüzleşme sonucunda cinsiyetçi davranışları yapan kişiler, yaptıklarının farkına vararak, gelecekte bu tür davranışları yapmamayı öğrenebilmektedir (Hyers, 2007). Cinsiyetçilikle yüzleşme neticesinde bireyler, cinsiyetçi davranışların kabul görmediğini fark edip, cinsiyetçiliğin olmaması gerektiğini kabullenebilir. Yüzleşme sonucunda, cinsiyetçi davranışta bulunan kişi, cinsiyetçi davranışlarını azaltır ise yüzleşen kișiyle aralarındaki ilișki olumluya (sevme, sayg1) gidebilmektedir (Hyers, 2007; Mallett ve Wagner, 2011). Bu bulgulara dayanarak, cinsiyetçilikle yüzleşmenin sosyal değişim için gerekli bir adım olduğu söylenebilir.

\section{Grup Temelli Olumlu veya Olumsuz Çıktılar}

Kadınlara grup olarak yaklaşıldığında ise cinsiyetçiliği meşrulaştırma, var olan sistemin devam etmesini sağladığından, sosyal değişime engel olmakta ve kadının statüsünün iyileşmesini engellemektedir. Cinsiyetçi sistemi meşrulaştırmada önemli bir rol oynayan korumacı cinsiyetçilik, kadınların zayıflığını ve güçsüzlüğünü olumlu bir tonla vurgulamaktadır. Bu cinsiyetçiliği benimseyen kadınların motivasyonlarının ve performanslarının düştüğü bulunmuştur (Dardenne ve ark., 2007). Becker ve Wright (2011) korumacı cinsiyetçilikte yüksek olan kadınların cinsiyet ayrımcılığını azaltmaya güdülü olmadıklarını göstermiştir. Bunun gibi çalışmalar, korumacı cinsiyetçiliği benimseyen kadınların kolektif harekete katılmadıklarını gösterir niteliktedir. Bunun yanı sıra düşmanca cinsiyetçiliği benimseme de kadınlarda erkek gücünü ve baskınlığını destekleme anlamı taşıdığ 1 için kadınlar erkek egemen yapılarla ilgili sorun yaşamamakta ve cinsiyet sistemini desteklemektedir (Glick ve Fiske, 1996; Glick ve ark., 2000).

Benzer şekilde, kendini suskunlaştırma da sosyal değişimi engelleyen bir tepki türüdür. Kadınlar suskun- 
laştıklarında, var olan sorunların açıkça ortaya konulmasına ve tartışılmasına engeller oluşmaktadır. Cinsiyetçiliğin toplumsal bir sorun olduğu algısının oluşumu engellenmektedir. Azınlık etkileri alanyazınına göre, azınlıkların sosyal bir etki yaratabilmesi için yaşadıkları sorunu ortaya koyarak görünür hale gelmesi, bir çatışma oluşturması ve avantajlı grup ile mücadele etmesi gereklidir. Yaşanacak bu sosyal çatışma sayesinde çoğunluk sorunun farkına varacak ve var olan durumu sorgulamaya başlayacaktır (Moscovici, 1976). Bu açıdan cinsiyetçilik ile yüzleşme ve kolektif kadın hareketleri, sosyal değişim için önemli bir role sahip olabilir. Daha önce belirtildiği gibi, cinsiyetçilikle yüzleşme bireysel düzeyde farkındalık yaratıp, cinsiyetçiliğin zararlarını göz önüne sererek kolektif harekete katk1 sağlayabilir (Hyers, 2007)

Cinsiyetçilikle yüzleşme gibi bireysel çabalar kolektif amaca hizmet edebilir. Kolektif kadın hareketleri ise kadınların dezavantajlı konumunu belirgin hale getirip erkeklere ve cinsiyetçiliği meşrulaştıran kadınlara daha eşitlikçi alternatif bir toplumsal yapının mümkün olduğunu gösterebilir. Tutarlı kadın hareketleri, cinsiyet eşitsizliği durumunu gözler önüne sermeye ve var olan adaletsiz durumun sorgulanmasına yardımcı olabilir. $\mathrm{Bu}$ durumda azınlık grubu olarak ele alınan kadınların sosyal etki yaratma olasılığı oluşabilir.

\section{Sonuç}

Bu makalede kadınların cinsiyetçiliğe verebileceği farklı tepkiler ele alınmıştır. Cinsiyetçilik farkındalığı ve cinsiyetçiliğe verilen tepkide pasif veya aktif olma boyutlarına bağlı olarak kabullenme-meşrulaştırma, kendini suskunlaştırma, cinsiyetçilikle yüzleşme ve kolektif kadın hareketlerine katılma olmak üzere dört farklı tepki türü sunulmuştur. Kadınlar farklı amaçlarla ve güdülerle farklı tepkilerde bulunabilir. Bu tepkilerin altında yatan nedenler, kişiler arası ilişkilerinde çatışma/sorun yaşamamak, cinsiyetçi davranan kişiyi eğitmek, cinsiyetçiliğe karşı sahip oldukları tutumlar ve değerler nedeniyle benliklerini göstermek, kendi imajlarını korumak (savunmasız görünmemek gibi) ve enerji harcamamak gibi çeşitlilik gösterebilir (Hyers, 2007). Hyers'a (2007) göre, çatışmadan kaçınma ve zaman/enerji harcamak istememe toplumdaki cinsiyet kurallarına ve rollerine uygun davranışlarken; cinsiyetçi kişiyi eğitmek, cinsiyetçi olmadığını gösterip, böyle bir imaj yaratma çabası, aktivizm sosyal kurallarına ve rollerine uygun davranışlardır. Ayrıca, kadınlar tercih ettikleri tepkiler sonucunda kendilerince bazı yararlar sağlayabilir. Kendilerini suskunlaştıran kadınlar, çatışmadan kaçınarak toplumla uyum içinde yaşadıklarını düşünebilir (van Lange ve ark., 1997) ya da duygusal olarak rahatsızlık ve suçluluk hissedebilir (Fairchild ve Rudman, 2008; Jack ve Dill,
1992). Cinsiyetçilikle yüzleşen veya kolektif hareketler gösteren kadınlar ise birey veya grup temelli olarak cinsiyetçiliğe karşı olduklarını ve sosyal değiş̧im yapılması gerektiğini göstermiş olur (Hyers, 2007).

Ele alınan dört farklı tepkinin farklı zamanlarda aynı kadın tarafından yapılması söz konusu olabilir. Kadınlar, yaş ve sosyal gelişimleri sonucu farklı dönemlerde, farklı tepkiler verebilir. Makalede belirtildiği gibi, kadınların kendi yaşantılarındaki değişim, farklı deneyimler kazanma, farklı cinsiyetçi ve ayrımcı davranışlara maruz kalma, feministlerle sosyal temasta bulunma ve eğitim alma gibi birçok unsur nedeniyle tepkilerinin değişmesi söz konusudur (Nelson ve ark., 2008). Kadınların, kadın veya feminist kimliklerine bağl1lıkları zaman içinde farklı nedenlerle değişebilir. Örneğin, geleneksel cinsiyet kalıpyargılarını ve toplumsal cinsiyet rollerini benimseyen ve meşrulaştıran bir kadın eğitim ya da üstte belirtilen bazı nedenlerden dolayı cinsiyetçiliğin farkına daha kolay varabilir ve suskun kalmayabilir. Feminist görüşlere daha olumlu yaklaşıp, kendisi gibi diğer kadınların da yaşadığı cinsiyetçiliği azaltmak adına kolektif hareketi tercih edebilir (bkz. Downing ve Roush, 1985).

$\mathrm{Bu}$ değişim süreci her kadın için farklı süreçlerde ve sürelerde olabilir. Kadının cinsiyetçilik düzeyi, yaşanan ortamın cinsiyetçilik iklimi, ekonomik durumu ve kadının deneyimleri gibi birçok unsur bu süreçleri ve süreyi etkileyebilir. Yakın zamanda yapılan bir nitel araştırmada (Savaş ve Stewart, 2019) görüşme tekniği kullanılarak kadınların neden ve nasıl feminist aktivist oldukları incelenmiştir. Göreli yoksunluk ve sosyal kimlik bulgularını destekler nitelikte, bu çalışmada belirlenen en önemli değişken adaletsizlik algısıdır. Kadınların bir kısmı yaşadıkları cinsiyetçi durumları normalleştirdiklerini ama yıkıcı (çok rahatsız edici) deneyimler ile kadın-erkek eşitsizliğinin farkına vardıklarını, aktivist olmaya başladıklarını ve bir dönüşüm yaşadıklarını belirtmişlerdir. $\mathrm{Bu}$ yıkıcı deneyimler ailelerinde erkek kardeşlerine ve kendilerine yapılan farklı muamelelerin farkına varma, sosyal yaşamda ayrımcılığa uğrama ve baskıcı politik rejimler gibi olaylardır. Bu yaşantıların birikerek çoğalması, kadınların cinsiyetçiliği algılamasına ve rahatsızlık duymasına yol açmıştır. Bu durum kadınları kolektif harekete itmiştir. Kendileri gibi düşünen kişilerle birlikte hareket etmek, onlardan sosyal destek ve sevgi-saygı bulmak feminist hareketlere bağlilıklarını arttırmıştır. Buna göre, yaşadığı ortamlardaki adaletsizlikten rahatsız olan kadınların kolektif hareketi tercih etme olasılı̆̆ 1 daha fazladır.

Kısacası, kadınların cinsiyetçiliğe tepkilerini etkileyecek birçok değişken vardır. Ele alınan değişkenler bireysel, ortamsal ve durumsal olmak üzere üç başlık altında toplanabilir. Bireysel olarak hem kadınların hem de kadınların iletişimde bulundukları diğer bireylerin 
cinsiyetçiliği algılayış düzeyi, farkındalığı, davranışları belirli bir nedene yükleme şekilleri, toplumsal kurallara ve rollere bağlılığı, farklı konulardaki tutumları cinsiyetçiliğe tepkileri değiştirebilir. Bireysel özelliklerin yanında cinsiyetçi tavır ve davranışların hangi ortamda (örn., sokak, ev, iş yeri, eğitim kurumları, internet, sosyal medya) olduğu da önemlidir. Farklı ortamlar, farklı tepkilerin oluşmasına neden olabilir. Bir bireyin belirli bir ortamda yaşanan durumu algılamasını ve değerlendirmesini, durumun muğlak veya net olması, algilanan tehdit, toplumsal kurallar ve kültür etkileyecektir (Fitzgerald ve ark., 1995). Kültür açısından bakıldığında, örneğin, Türk kadınlar Amerikalı kadınlara oranla taciz edenlerden daha fazla kaçınmaktadır (Wasti ve Cortina, 2002). Ek olarak, cinsel tacizde bulunmuş kişilerin alması gereken cezalar konusunda Amerikan katılımcilar Alman ve Hollandal1lara göre daha ciddi cezalar önermiştir (Sigal ve Jacobsen, 1999).

Ayrıca, cinsiyetçiliğe tepki verme durumu hem rahatsızlık ve zarar veren cinsiyetçiliği bir sorun olarak görüp, bu sorunla uğraşmayı ve değiştirmeyi gerektirir; hem de bu yaşananlar sırasında duygulara (örn., kafa karışıklığı, stres, üzüntü, korku, şok olma, gücenme, çaresizlik ve depresyon) odaklanıp, onları düzenlemeyi gerektirir (Fitzgerald ve ark., 1995). Cinsiyetçiliğe tepki, bilişsel, duygusal ve davranışsal yönleriyle ele alınabilecek bir süreçtir. $\mathrm{Bu}$ açıdan tutum değișimi süreçlerini de içerir. Farklı tutum değişimi kuramları (örn., Petty ve Caccioppo'nun Detaylı İnceleme Olasılığı Kuramı; Muzaffer Şerif'in Sosyal Muhakame Kuramı; Jack Brehm'in Psikolojik Tepkisellik Kuramı; bkz. Sakallı-Uğurlu, 2018) kullanılarak cinsiyetçi tutum ve davranışları değiştirme olasılığı vardır. Uygulamalı sosyal psikoloji alanında çalışanların hem kadınlar hem de erkekler için bu tür tutum değiştirme programları hazırlamaları toplum için faydalı olacaktır. Tutum değişimi ve iknanın yanı sıra bu tür cinsiyetçi tutumların daha baştan oluşmaması için müdahele programları hazırlamak daha da yerinde olacaktır. Son olarak, cinsiyetçiliği biyolojik temellere oturtmamak gerektiğini vurgulamakta yarar vardır. Biyolojik olarak dişi ve eril olunsa bile toplumsal ve kültürel temelli olarak kadınsılık ve erkeksilik özelliklerinin buyurgan bir şekilde kişilere yüklenmemesi gereklidir. Örneğin, doğurganlığı ve emzirme özelliği nedeniyle çocuk bakımını ve yetiştirmeyi kadınlara yüklemek, onları sadece anne rolleri ile değerlendirmek ve aile içinde sadece eş ve anne olarak görmek; buna karşın erkekleri bu tür rollerden muaf tutmak eşitlikçi yaklaş1ma uymamaktadır. Kadın ve erkeklerin bedensel ve biyolojik farklılıkları olsa bile cinsiyet rolleri ve buyurgan kalıpyargılarla onlara yüklenen zorunlulukların ortadan kaldırılması ve cinsiyetler arası adil olunması önemlidir. Kadınların cinsiyet eşitsizliğini algılar hale gelmeleri, bu konularda toplum içinde açıkça konuşabilmeleri, yaşadikları adaletsizlikleri dile getirebilmeleri ve toplumsal bir değişim sağlamak amacıyla kolektif hareketlere katılmaları sosyal değişimin oluşumuna katkı sağlayacaktır.

Sonuç olarak, üstteki bilgiler 1şı̆̆ında, toplumda cinsiyetçiliğe tepki verilebilecek bir iklimin yaratılması ve cinsiyetçiliğin kabul edilemez olduğu ile ilgili normların oluşturulması yerinde olacaktır. Bu tür konularda politik, hukuki ve eğitimsel alt yapılar sağlanmalıdır. Bunların yanı sıra sosyoloji, kadın çalışmaları veya toplumsal cinsiyet çalışmaları, siyasal bilimler, hukuk ve sosyal psikoloji gibi farklı sosyal bilim alanlarında cinsiyetçiliğe tepkiler ve cinsiyetçilikte değişim konuları daha detaylı ele alınmalıdır. Bu tür konuları anlamak, tahmin etmek ve cinsiyetçilik açısından sosyal bir değişimi sağlayabilecek değişkenleri içeren bilimsel çalışmalar yapmak cinsiyet eşitliği sağlamak açısından önemlidir. 


\section{Kaynaklar}

Altemeyer, B. (1998). The other "authoritarian personality." Advances in Experimental Social Psychology, 30, 47-92.

Anderson, C. ve Berdahl, J. L. (2002). The experience of power: Examining the effects of power on approach and inhibition tendencies. Journal of Personality and Social Psychology, 83, 1362-1377. doi: 10.1037/0022-3514.83.6.1362.

Ashburn-Nardo, L., Blanchar, J. C., Petersson, J., Morris, K. A. ve Goodwin, S. A. (2014). Do you say something when it's your boss? The role of perpetrator power in prejudice confrontation. Journal of Social Issues, 70(4), 615-636.

Ashburn-Nardo, L., Morris, K. A. ve Goodwin, S. A. (2008). The confronting prejudiced responses (CPR) model: Applying CPR in organizations. Academy of Management Learning and Education, 7(3), 332-342. doi: 10.5465/AMLE.2008.34251671

Ayres, M. M., Friedman, C. K. ve Leaper, C. (2009). Individual and situational factors related to young women's likelihood of confronting sexism in their everyday lives. Sex Roles, 61, 449-460. doi: 10.1007/s11199-009-9635-3

Bandura, A. (1977). Self-efficacy: Toward a unifying theory of behavioral change. Psychological Review, 84(2), 191-215.

Bargad, A. ve Hyde, J. S. (1991). Women's studies: A study of feminist identity development in women. Psychology of Women Quarterly, 15, 181-201.

Barreto, M. ve Ellemers, N. (2005). The burden of benevolent sexism: How it contributes to the maintenance of gender inequalities. European Journal of Social Psychology, 35, 633-642. doi: 10.1002/ ejsp. 270

Becker, J. C., Glick, P., Ilic, M. ve Bohner, G. (2011). Damned if she does, damned if she doesn't: Consequences of accepting versus confronting patronizing help for the female target and male actor. $\mathrm{Eu}$ ropean Journal of Social Psychology, 41, 761-773. http://dx.doi.org/10.1002/ejsp.823

Becker, J. C. ve Swim, J. K. (2012). Reducing endorsement of benevolent and modern sexist beliefs: Differential effects of addressing harm versus pervasiveness of benevolent sexism. Social Psychology, 43, 127-137. http://dx.doi.org/10.1027/18649335/a000091

Becker, J. C. ve Wright, S. C. (2011). Yet another dark side of chivalry: Benevolent sexism undermines and hostile sexism motivates collective action for social change. Journal of Personality and Social Psychology, 101 (1), 62-77. doi: 10.1037/a0022615
Bergman, M. E., Langhout, R. D., Polmieri, P. A., Cortnina, L. M. ve Fitzgerald, L. F. (2002). To tell or not to tell? Antecedents and consequences of reporting harassment. Journal of Applied Psychology, 87, 230-242.

Berryman-Fink, C. ve Verderber, K. S. (1985). Attributions of the term feminist: A factor analytic development of a measuring instrument. Psychology of Women Quarterly, 9(1), 51-64. http://dx.doi. org/10.1111/j.1471-6402.1985.tb00860.x

Brandt, M. J. (2012). Sexism and gender inequality across 57 societies. Research Report, 22(11), 14131418. doi: 10.1177/0956797611420445

Brant, C. R., Mynatt, C. R. ve Doherty, M. E. (1999). Judgments about sexism: A policy capturing approach. Sex Roles, 41(5/6), 347-374.

Burn, S., Aboud, R. ve Moyles, C. (2000). The relationship between gender social identity and support for feminism. Sex Roles, 42, 1081-1089. doi: 10.1023/A:1007044802798

Canary, D. J. ve Cupach, W. R. (1988). Relational and episodic characteristics associated with conflict tactics. Journal of Social and Personal Relationships, 5, 305-325.

Calogero, R. M. ve Jost, J. T. (2011). Self-subjugation among women: Exposure to sexist ideology, self-objectification, and the protective function of the need to avoid closure. Journal of Personality and Social Psychology, 100(2), 211-228.

Connelly, K. ve Heesacker, M. (2012). Why is benevolent sexism appealing? Associations with system justification and life satisfaction. Psychology of Women Quarterly, 36(4), 432-443.

Cottrell, C. A. ve Neuberg, S. (2005). Different emotional reactions to different groups: A sociofunctional threat-based approach to "prejudice". Journal of Personality and Social Psychology, 88(5), 770789. https://doi.org/10.1037/0022-3514.88.5.770

Cramer, K. M., Gallant, M. D. ve Langlois, M. W. (2005). Self-silencing and depression in women and men: Comparative structural equation models. Personality and Individual Differences, 39(3), 581-592. http://dx.doi.org/10.1016/j. paid.2005.02.012

Crosby, F. (1976). A model of egoistical relative deprivation. Psychological Review, 83, 85-113.

Crosby, F. (1984). The denial of personal discrimination. American Behavioral Scientist, 27(3), 371-386. https://doi.org/10.1177/000276484027003008

Czopp, A. M. ve Monteith, M. J. (2003). Confronting prejudice (literally): Reactions to confrontations of racial and gender bias. Personality and Social Psychology Bulletin, 29, 532-544. 
Dambrun, M. (2007). Gender differences in mental health: The mediating role of perceived personal discrimination. Journal of Applied Social psychology, 37, 1118-1129. doi: 10.1111/i.15591816.2007.00202.x.

Dardenne, B., Dumont, M. ve Bollier T. (2007). Insidious dangers of benevolent sexism: Consequences for women's performance. Journal of Personality and Social Psychology, 93(5), 764-79. doi: 10.1037/0022-3514.93.5.764

Dickter, C. L., Kittel, J. A. ve Gyurovski, I. I. (2012). Perceptions of non-target confronters in response to racist and heterosexist remarks. European Journal of Social Psychology, 42(1), 112-119. http:// dx.doi.org/10.1002/ejsp.855

Duncan, L. E. (1999). Motivation for collective action: Group consciousness as mediator of personality, life experiences, and women's rights activism. $\mathrm{Po}$ litical Psychology, 20(3), 611-635.

Dumont, M., Sarlet, M. ve Dardenne, B. (2010). Be too kind to a woman, she'll feel incompetent: Benevolent sexism shifts self-construal and autobiographical memories toward incompetence. Sex Roles: A Journal of Research, 62(7-8), 545-553. http:// dx.doi.org/10.1007/s11199-008-9582-4

Dodd, E. H., Giuliano, T. A., Boutell, J. M. ve Moran, B. E. (2001). Respected or rejected: Perceptions of women who confront sexist remarks. Sex Roles, 45, 567-577.

Downing, N. E. ve Roush, K. L. (1985). From passive acceptance to active commitment: A model of feminist identity development for women. The Counseling Psychologists, 13(4), 695-709. https://doi. org/10.1177/0011000085134013

Downey, G. ve Feldman, S. (1996). Implications of rejection sensitivity for intimate relationships. Journal of Personality and Social Psychology, 70, 1327-1343. doi:10.1037/0022-3514.70.6.1327

Dökmen, Z. (2000). Kendi cinsiyetindekilere ve diğer cinsiyettekilere ilişkin alg1, cinsiyet rolleri ve depresyon ilişkileri. Kriz Dergisi, 9(1), 9-19.

Eagly, A. H. ve Chrvala, C. (1986). Sex differences in conformity: Status and gender role interpretations. Psychology of Women Quarterly, 10, 203-220. doi: 10.1111/j.1471-6402.1986.tb00747.x

Eagly, A. H. ve Mladinic, A. (1989). Gender stereotypes and attitudes toward women and men. Personality and Social Psychology Bulletin, 15(4), 543-558.

Eagly, A. H. ve Steffen, V. J. (1984). Gender stereotypes stem from the distribution of women and men into social roles. Journal of Personality and Social Psychology, 46, 735-754.

Eriksen, K. ve Kress, V. E. (2008). Gender and diagno- sis: Struggles and suggestions for counselors. Journal of Counseling \& Development, 86, 152-162. doi:10.1002/j.1556-6678.2008.tb00492.x

Fairchild, K. ve Rudman, L. A. (2008). Everyday stranger harassment and women's objectification. Social Justice Research, 21, 338-357. doi: 10.1007/ s11211-008-0073-0

Fitzgerald, L. F., Swan, S. ve Fischer, K. (1995). Why didn't she just report him? The psychological and legal implications of women's responses to sexual harassment. Journal of Social Issues, 51, 117-138.

Foster, M. D. ve Matheson, K. (1995). Double relative deprivation: Combining the personal and political. Personality \& Social Psychology Bulletin, 21, 1167-1177.

Fredrickson, B. L. ve Roberts, T. (1997). Objectification theory: Toward understanding women's lived experiences and mental health risks. Psychology of Women Quarterly, 21, 173-206.

Gervais, S. J., Hillard, A. L. ve Vescio, T. K. (2010). Confronting sexism: The role of relationship orientation and gender. Sex Roles, 63, 463-474. doi: 10.1007/s11199-010-9838-7.

Glick, P. ve Fiske, S. T. (1996). The Ambivalent Sexism Inventory: Differentiating hostile and benevolent sexism. Journal of Personality and Social Psychology, 70, 491-512. doi: 10.1037/00223514.70.3.491.

Glick, P. ve Fiske, S. T. (2001). An ambivalent alliance: Hostile and benevolent sexism as complementary justification for gender inequality. American Psychologist, 56(2), 109-118. Doi: 10.1037/0003066x.56.2.109.

Glick, P., Fiske, S. T., Mladinic, A. ve ark. (2000). Beyond prejudice as simple antipathy: Hostile and benevolent sexism across cultures. Journal of Personality and Social Psychology, 75, 763-775.

Goldenhar, L. M., Swanson, N. G., Hurrell, J. J., Jr., Ruder, A. ve Deddens, J. (1998). Stressors and adverse outcomes for female construction workers. Journal of Occupational Health Psychology, 3, 19-32.

Good, J. J., Moss-Racusin, C. A. ve Sanchez, D. T. (2012). When do we confront? Perceptions of costs and benefits predict confronting discrimination on behalf of the self and others. Psychology of Women Quarterly, 36, 210-226. doi: 10.1177/0361684312440958

Gutek, B. A. ve Koss, M. P. (1993). Changed women and changed organization: Consequences of and coping with sexual harassment. Journal of Vocational Behavior, 42, 28-48.

Haddock, G. ve Zanna, M. P. (1994). Preferring "housewives" to "feminist": Categorization and the favor- 
ability of attitudes toward women. Psychology of Women Quarterly, 18, 25-52.

Hammond, M. D. ve Sibley, C. G. (2011). Why are benevolent sexists happier? Sex Roles, 65, 332-343. doi: 10.1007/s11199-011-0017-2

Harris, R. J. ve Firestone, J. M. (1997). Subtle sexism in the U.S. military: Individual responses to sexual harassment. In Benokraitis, N. V. (Ed.), Subtle sexism: Current practice and prospects for change içinde (pp. 154-171). Sage.

Heinberg, L. J., Thompson, J. K. ve Stormer, S. (1995). Development and validation of the sociocultural attitudes towards appearance questionnaire. International Journal of Eating Disorders, 17(1), 8189. http://dx.doi.org/10.1002/1098-108X

Henderson-King, D. ve Stewart, A. J. (1997). Feminist consciousness: Perspectives on women's experiences. Personality \& Social Psychology Bulletin, 23, 415-427.

Hurst, R. J. ve Beesley, D. (2013). Percieved sexism, self-silencing, and psychological distress in college women. Sex Roles, 68, 311-320. doi: 10.1007/ s11199-012-0253-0

Hyers, L. L. (2007). Resisting prejudice every day: Exploring women's assertive responses to anti-black racism, anti-semitism, heterosexism, and sexism. Sex Roles, 56, 1-12. doi: 10.1007/s11199-0069142-8

Impett, E. A., Gable, S. L. ve Peplau, A. (2005). Giving up and giving in: The costs and benefits of daily sacrifice in intimate relationships. Journal of Personality and Social Psychology, 89(3), 327-344. doi: 10.1037/0022-3514.89.3.327

Jack, D. C. (1991). Silencing the self: Women and depression. Harvard University Press.

Jack, D. C. ve Dill, D. (1992). The Silencing the Self Scale: Schemas of intimacy associated with depression in women. Psychology of Women Quarterly, 16(1), 97-106.

Jost, J. T. (1997). An experimental replication of the depressed-entitlement effect among women. Psychological Women Quarterly, 21, 387-393.

Jost, J. T. ve Banaji, M. R. (1994). The role of stereotyping in system-justification and the production of false consciousness. British Journal of Social Psychology, 33(1), 1-27. http://dx.doi. org/10.1111/j.2044-8309.1994.tb01008.x

Jost, J. T. ve Kay, A. C. (2005). Exposure to benelovent sexism and complementary gender stereotypes: Consequences for specific and diffuse forms of system justification. Journal of Personality and Social Psychology, 88(3), 498-509. doi: 10.1037/00223514.88.3.498.
Kaiser, C. R. ve Miller, C. T. (2003). Derogating the victim: The interpersonal consequences of blaming events on discrimination. Group Processes and Intergroup Relations, 6, 227-237.

Kaiser, C. R. ve Miller, C. T. (2004). A stress and coping perspective on confronting sexism. Psychology of Women Quarterly, 28, 168-178. doi:10.1111/ j.1471-6402.2004.00133.x

Kaynak-Malatyalı, M., Kaynak, B. D. ve Hasta, D. (2017). A social dominance theory perspective on attitudes toward girl child marriage in Turkey: The legitimazing role of ambivalent sexism. Sex Roles, 77, 687-696. doi: 10.1007/s11199-017-0750-2.

Klandermans, B. (1986). Perceived costs and benefits of participation in union action. Personnel Psychology, 39, 379-397.

Klandermans, B. (1989). Grievance interpretation and success expectations: The social construction of protest. Social Behavior, 4, 113-125.

Kelly, C. (1993). Group identification, intergroup perceptions and collective action. In W. Stroebe ve M. Hewstone (Eds). European review of social psychology. vol. 4. John Wiley \& Sons Ltd.

Kelly, C. ve Breinlinger, S. (1995). Identity and injustice: Exploring women's participation in collective action. Journal of Community and Applied Social Psychology, 5, 41-57. doi: 10.1002/ casp. 2450050104

Klonoff, E.A., Landrine, H. ve Campbell, R. (2000). Sexist discrimination may account for well-known gender differences in psychiatric symptoms. Psychology of Women Quarterly, 24, 93-99. doi: 10.1111/j1471-6402.2000.tb01025.x.

Knapp, D.E., Faley, R. H., Ekeberg, S. E. ve DuBois, C. L. Z. (1997). Determinants of target responses to sexual harassment: A conceptual framework. Academy of Management Review, 22, 687-729.

Krieger, N. (1990). Racial and gender discrimination: Risk factors for high blood pressure? Social Science \& Medicine, 30, 1273-1281.

Kowalski, R. M. (1996). Complaints and complaining: Functions, antecedents, and consequences. Psychological Bulletin, 119, 179-196.

Lamb, L. M., Bigler, R. S., Liben, L. S. ve Green, V. A. (2009). Teaching children to confront peers' sexist remarks: Implications for theories of gender development and educational practice. Sex Roles, 61, 361-382. doi: 10.1007/s11199-009-9634-4.

Landrine, H., Klonoff, E. A., Gibbs, J., Maning, V. ve Lund, M. (1995). Physical and psychiatric correlates of gender discrimination: An application of the schedule of sexist events. Psychology of Women Quarterly, 19, 473-492. doi: 10.1111/j.1471-6402.1995.tb00087.x. 
Laurin, K., Kay, A. C. ve Shepherd, S. (2011). Self-stereotyping as a route to system justification. Social Cognition, 29, 360-375.

Leach, C. W., van Zomeren, M., Zebel, S., Vliek, M. L. W., Pennekamp, S. F., Doosje, B., ... Spears, R. (2008). Group-level self-definition and self-investment: A hierarchical (multi-component) model of in-group identification. Journal of Personality and Social Psychology, 95(1), 144-165. doi: 10.1037/0022-3514.95.1.1444

Leaper, C. ve Arias, D. M. (2011). College women's feminist identity: A multidimensional analysis with implications for coping with sexism. Sex Roles, 64(7-8), 475-490. doi: 10.1007/s11199-011-9936-1

Liss, M., Crawford, M. ve Popp, D. (2004). Predictors and correlates of collective action. Sex Roles, 50(11-12), 771-779.

Liss, M. ve Erchull, M. J. (2010). Everyone feels empowered: Understanding feminist self-labeling. Psychology of Women Quarterly, 34(1), 85-96. http:// dx.doi.org/10.1111/j.1471-6402.2009.01544.x

Liss, M., O'Connor, C., Morosky, E. ve Crawford, M. (2001). What makes a feminist? Predictors and correlates of feminist social identity in college women. Psychology of Women Quarterly, 25, 124-133.

London, B., Downey, G., Bonica, C. ve Paltin, I. (2007). Social causes and consequences of rejection sensitivity. Journal of Research on Adolescence, 17, 481-506. doi: 10.1111/j.1532-7795.2007.00531.x

London, B., Downey, G., Romero-Canyas, R., Rattan, A. ve Tyson, D. (2012). Gender-based rejection sensitivity and academic self-silencing in women. Journal of Personality and Social Psychology, 102(5), 961-979.

Magley, V. J. (2002). Coping with sexual harassment: Reconceptualizing women's resistance. Journal of Personality and Social Psychology, 83(4), 930-946.

Mahalik, J. R., Morray, E. B., Coonerty-Femiano, A. ve ark. (2005). Development of the conformity to feminine norms inventory. Sex Roles, 52, 417. https://doi.org/10.1007/s11199-005-3709-7

Maji, S. ve Dixit, S. (2019). Self-silencing and women's health: A review. International Journal of Social Psychiatry, 65, 3-13. doi: 10.1177/0020764018814271

Major, B., Quinton, W. J. ve McCoy, S. K. (2002). Antecedents and consequences of attributions to discrimination: Theoretical and empirical advances. In M. P. Zanna (Ed.), Advances in experimental social psychology içinde (pp. 251-330). Academic Press. http://dx.doi.org/10.1016/S0065-2601(02)80007-7

Major, B., Quinton, W. J. ve Schmader, T. (2003). Attributions to discrimination and self-esteem: Impact of group identification and situational ambiguity. Journal of Experimental Social Psychology, 39, 220-231. doi: 10.1016/50022-1031(02)00547-4

Mallett, R. K. ve Wagner, D. E. (2011). The unexpectedly positive consequences of confronting sexism. Journal of Experimental Social Psychology, 47, 215-220. doi: 10.1016/jjesp.2010.10.001

Meijs, M. H., Ratliff, K. A., ve Lammers, J. (2017). The discrepancy between how women see themselves and feminists predicts identification with feminism. Sex Roles, 77, 293-308. Doi: 10.1007/ s11199-016-0733-8

Moradi, B. ve Subich, L. M. (2002). Perceived sexist events and feminist identity development attitudes: Links to women's psychological distress. The Counseling Psychologist, 30, 44-65. doi: 10.1177/0011000002301003

Moscovici, S. (1976). Social influence and social change. New York: Academic press.

Moya, M., Glick, P., Exposito, F., de Lemus, S. ve Hart, J. (2007). It's for your own good: benevolent sexism and women's reactions to protectively justified restrictions. Personality and Social Psychology Bulletin, 33 (10), 1421-1434. doi: 10.1177/0146167207304790

Napier, J. L., Thorisdottir, H. ve Jost, J. T. (2010). The joy of sexism? A multinational investigation of hostile and benevolent justifications for gender inequality and their relations to subjective well-being. Sex Roles, 62, 405-419. doi: 10.1007/s11199009-9712-7

Nelson, J. A., Liss, M., Erchull, M. J., Hurt, M. M., Ramsey, L. R., Turner, D. L., ... Haines, M. E. (2008). Identity in action: Predictors of feminist self-identification and collective action. Sex Roles, 58(910), 721-728. https://doi.org/10.1007/s11199-0079384-0.

Nolen-Hoeksema, S. (2001). Gender differences in depression. Current Directions in Psychological Science, 10, 173-176. doi: 10.1111/1467-8721.00142

Pratto, F., Sidanius, J. ve Levin, S. (2006). Social dominance theory and the dynamics of inter-group relations: Taking stock and looking forward. European Review of Social Psychology, 17, 271-320.

Pratto, F., Sidanius, J., Stallworth, L. M. ve Malle, B. F. (1994). Social dominance orientation: A personality variable predicting social and political attitudes. Journal of Personality \& Social Psychology, 67, $741-763$.

Radke, H. R. M., Hornsey, M. J. ve Barlow, F. K. (2016). Barriers to women engaging in collective action to overcome sexism. American Psychologist, 71(9), 863-87. http://dx.doi.org/10.1037/a0040345 
Ramsey, L. R., Haines, M. E., Hurt, M. M., Nelson, J.A., Turner, D. L., Liss, M. ve Erchull, M. J. (2007). Thinking of others: Feminist identification and the perception of others' beliefs. Sex Roles, 56, 611616. doi: 10.1007/s11199-007-9205-5

Redford, L., Howell, J. L., Meijs, M. H. J. ve Ratliff, K. A. (2016). Implicit and explicit attitudes toward feminist prototypes predict identification as feminist. Group Processes \& Intergroup Relations, 21(1), 3-18. doi: 10.1177/1368430216630193

Reid, A. ve Purcell, N. (2004). Pathways to feminist identification. Sex Roles, 50, 759-769.

Robnett, R. D., Anderson, K. J. ve Hunter, L. E. (2012). Predicting feminist identity: Associations between gender-traditional attitudes, feminist stereotyping, and ethnicity. Sex Roles, 67, 143-157. doi:10.1007/ s11199-012-0170-2

Roy, R., Weibust, K. S. ve Miller, C. T. (2007). Effects of stereotypes about feminists on feminist self-identification. Psychology of Women Quarterly, 31, 146-156.

Rudman, L. A. ve Glick, P. (2001). Prescriptive gender stereotypes and backlash toward agentic women. Journal of Social Issues, 57(4), 743-762. http://dx. doi.org/10.1111/0022-4537.00239

Rusbult, C. E. ve Van Lange, P. A. M. (1996). Interdependence processes. In E. T. Higgins \& A. W. Kruglanski (Eds.), Social psychology: Handbook of basic principles (pp. 564-596). Guilford Press.

Sabik, N. J. ve Tylka, T. L. (2006). Do feminist identity styles moderate the relation between perceived sexist events and disordered eating? Psychology of Women Quarterly, 30(1), 77-84. http://dx.doi. org/10.1111/j.1471-6402.2006.00264.x

Sanchez, D. T., Crocker, J. ve Boike, K. R. (2005). Doing gender in the bedroom: Investing in gender norms and the sexual experience. Personality and Social Psychology Bulletin, 31, 1445-1455.

Sakallı, N. (2001). Kadın hakları: Farklı terimler, farklı tutumlar. Tecrübi Psikoloji Çalışmaları, 22, 1-13.

Sakallı-Uğurlu, N. (2003). Cinsiyetçilik: Kadınlara ve erkeklere ilişkin tutumlar ve çelişik duygulu cinsiyetçilik. Türk Psikoloji Yazıları, 6(11), 1-20.

Sakall1-Uğurlu, N. (2018). Sosyal psikolojide tutumlar ve tutum değişimi. İmge Kitabevi.

Sakall1-Uğurlu, N. ve Akbaş, G. (2013). Namus kültürlerinde "namus" ve "namus adına kadına şiddet": Sosyal psikolojik açıklamalar. Türk Psikoloji Yazılarl, 16 (32), 76-91.

Sakallı, N. ve Türkoğlu, B. (2019). "Erkek” olmak ya da olmamak: Sosyal psikolojik açıdan erkeksilik/erkeklik çalışmaları. Türk Psikoloji Yazılarl, 22(44), 77-79. doi: 10.31828/ tpy1301996120190516m00014
Sakall1-Uğurlu, N., Türkoğlu, B. ve Kuzlak, A. (2018). How are women and men perceived? Structure of gender stereotypes in contemporary Turkey. NESNE Psikoloji Dergisi, 6(13), 309-336. doi: 10.7816/nesne-06-13-04

Sakallı-Uğurlu, N., Türkoğlu, B., Kuzlak, A. ve Gupta, A. (2021). Stereotypes of single and married women and men in Turkish culture. Current Psychology, 40, 213-225. https://doi.org/10.1007/s12144018-9920-9

Savaş, Ö., \& Stewart, A. J. (2019). Alternative pathways to activism: Intersections of social and personal pasts in the narratives of women's rights activists. Qualitative Psychology, 6(1), 27-46. https://doi. org/10.1037/qup0000117

Shelton, J. N. ve Stewart, R. E. (2004). Confronting perpetrators of prejudice: The inhibitory effects of social costs. Psychology of Women Quarterly, 28, 215-223.

Shelton, J. N. ve Richeson, J. A. (2005). Intergroup contact and pluralistic ignorance. Journal of Personality and Social Psychology, 88, 91-107.

Sechrist, G. B., Swim, J. K. ve Stangor, C. (2004). When do the stigmatized make attributions to discrimination occurring to the self and others? The roles of self-presentation and need for control. Journal of Personality and Social Psychology, 87(1), 111-122.

Sibley, C. G., Overall, N. C. ve Duckitt, J. (2007). When women become more hostilely sexist toward their gender: The system-justifying effect of benevolent sexism. Sex Roles: A Journal of Research, 57(910), 743-754. http://dx.doi.org/10.1007/s11199007-9306-1

Sidanius, J., Levin, S., Liu, J. ve Pratto, F. (2000). Social dominance orientation, anti-egalitarianism and the political psychology of gender: An extension and cross-cultural replication. European Journal of Social Psychology, 30(1), 41-67. http://dx.doi. org/10.1002/(SICI)1099-0992(200001/02)

Sigal, J. ve Jacobsen, H. (1999). A cross-cultural exploration of factors affecting reactions to sexual harassment. Psychology, Public Policy and Law, 5(3), 760-785.

Stangor, C., Sechrist, G. B. ve Jost, J. T. (2001). Social influence and intergroup beliefs: The role of perceived social consensus. In J. P. Forgas ve K. D. Williams (Eds.), The Sydney symposium of social psychology. Social influence: Direct and indirect processes içinde (pp. 235-252). Psychology Press.

Stangor, C., Swim, J. K., Van Allen, K. L. ve Sechrist, G. B. (2002). Reporting discrimination in public and private contexts. Journal of Personality and Social Psychology, 82, 69-76. 
Stangor, C., Swim, J. K., Sechrist, G. B., DeCoster, J., VanAllen, K. L. ve Ottenbreit, A. (2003). Ask, answer and announce: Three stages in perceiving and responding to discrimination. In W. Stroebe ve M. Hewstone (Eds.), European review of social psychology içinde (pp. 277 - 311). Psychology Press/ Taylor \& Francis

Swim, J. K. ve Hyers, L. L. (1999). Excuse me, what did you just say? Women's public and private responses to sexist remarks. Journal of Experimental Social Psychology, 35, 68-88. doi:10.1006/ jesp. 1998.1370

Swim, J. K., Hyers, L. L., Cohen, L. L. ve Ferguson, M. J. (2001). Everyday sexism: Evidence for its incidence, nature, and psychological impact from three daily diary studies. Journal of Social Issues, 57, 31-53. doi:10.1111/0022-4537.00200

Swim, J. K., Eyssell, K. M., Murdoch, E. Q. ve Ferguson, M. J. (2010). Self-silencing to sexism. Journal of Social Issues, 66, 493-507. doi:10.1111/j.15404560.2010.01658.x

Swim, J. K., Mallett, R., Russo-Devosa, Y. ve Stangor, C. (2005). Judgments of sexism: A comparison of the subtlety of sexism measures and sources of variability in judgments of sexism. Psychology of Women Quarterly, 29, 406-411.

Szymanski, D. M., Gupta, A., Carr, E. R. ve Stewart, D. (2009). Internalized misogyny as a moderator of the link between sexist events and women's psychological distress. Sex Roles, 61, 101-109. doi: 10.1007/s11199-009-9611-y

Tajfel, H. ve Turner, J. (1979). An integrative theory of intergroup conflict. In W. G. Austin \& S. Worchel (Eds). The social psychology of intergroup relations. Brook/Cole Publishing.

Teitelman, A. M., Tennille, J., Bohinski, J. M., Jemmott, L. S. ve Jemmott III, J. B. (2011). Unwanted unprotected sex: Condom coercion by male partners and self-silencing of condom negotiation among adolescent girls. Advances in Nursing Science, 34(3), 243-259.

van Breen, J. A., Spears, R., Kuppens, T. ve de Lemus, S. (2017). A multiple identity approach to gender: Identification with women, identification with feminists, and their interaction. Frontiers in Psychology, 8(1019). https://doi.org/10.3389/ fpsyg.2017.01019.

van Lange, P. A. M., Rusbult, C. E., Drigotas, S. M., Arriaga, X. M., Witcher, B. S. ve Cox, C. L. (1997). Willingness to sacrifice in close relationships. Journal of Personality and Social Psychology, 72, 1373-1395.

van Zomeren, M., Postmes, T. ve Spears, R. (2008). To- ward an integrative social identity model of collective action: A quantitative research synthesis of three socio-psychological perspectives. Psychological Bulletin, 134, 504-535.

Wakefield, J. R. H., Hopkins, N. ve Greenwood, R. M. (2012). Thanks, but no thanks: Women's avoidance of help-seeking in the context of a dependency-related stereotype. Psychology of Women Quarterly, 36(4), 423-431. doi: 10.1177/0361684312457659.

Wang, K. ve Dovidio, J. F. (2017). Perceiving and confronting sexism: The causal role of gender identity salience. Psychology of Women Quarterly, 41(1), 65-76. doi: 10.1177/0361684316670628.

Wasti, S. A. ve Cortina, L. M. (2002). Coping in context sociocultural determinants of responses to sexual harassment. Journal of Personality and Social Psychology, 83(2). 394-405.

Watson, L. B., ve Grotewiel, M. (2016). The protective role of commitment to social change in the relationship between women's sexist experiences and self-silencing. Sex Roles, 75, 139-150. doi: 10.1007/s11199-016-0594-1.

Watson, L. B., Robinson, D., Dispenza, F. ve Nazari, N. (2012). African American women's sexual objectification experiences: A qualitative study. Psychology of Women Quarterly, 36, 458-475. doi: 10.1177/0361684312454724.

Weis, A. S., Redford, L., Zucker, A. N., ve Ratliff, K. A. (2018). Feminist identity, attitudes toward feminist prototypes, and willingness to intervene in everyday sexist events. Psychology of Women Quarterly, 42(3) 279-290. doi: 10.1177/0361684318764694

Widman, L., Welsh, D. P., McNutty, J. K. ve Little, K. C. (2006). Sexual communication and contraceptive use in adolescent dating couples. Journal of Adolescence Health, 39(6), 893-899.

Williams, R. ve Wittig, M. A. (1997). "I am not feminist, but...": Factors contributing to the discrepancy between pro-feminist orientation and feminist social identity. Sex Roles, 37(11/12), 885-904. a Feminist, But...": Factors

Witte, T. H. ve Sherman, M. F. (2002). Silencing the self and feminist identity development. Psychological Reports, 90,1075-1083. doi: 10.2466/ PR0.90.4.1075-1083.

Whiffen, V. E., Foot, M. L. ve Thompson, J. M. (2007). Self-silencing mediates the link between marital conflict and depression. Journal of Social \& Personal Relationships, 24(6), 993-1006.

Wright, S. C. (2010). Collective action and social change. In I. F. Dovidio, M. Hewstone, P. Glick ve V. M. Esses (Eds). Handbook of prejudice, stereotyping, and discrimination içinde (pp. 577-595). Sage. 
Wright, S. C., Taylor, D. M. ve Moghaddam, F. M. (1990). Responding to membership in a disadvantaged group: From acceptance to collective protest. Journal of Personality and Social Psychology, 58, 993-1006. doi: 10.1177/0265407507084813

Woodzicka, J. A. ve LaFrance, M. (2001). Real versus imagined gender harassment. Journal of Social Issues, 57, 15-30.

Yeung, A., Kay, A. C. ve Peach, J. (2014). Anti-feminist backlash: The role of system justification in the rejection of feminism. Group Processes and Intergroup Relations, 17, 436-452.

Yoder, J. D., Tobias, A. ve Snell, A. F. (2011). When declaring "I am a feminist" matters: Labeling is linked to activism. Sex Roles, 64, 9-18. doi: 10.1007/s11199-010-9890-3

Yoder, J. D., Perry, R. L. ve Saal, E. I. (2007). What good is a feminist identity? Women's feminist identification and role expectations for intimate and sexual relationships. Sex Roles, 57, 365-372.

Zucker, A. N. (2004). Disavowing social identities: What it means when women say, "I'm not a feminist, but..." Psychology of Women Quarterly, 28(4), 423-435. https://doi.org/10.1111/j.14716402.2004.00159.x

Zucker, A. N. ve Bay-Cheng, L. Y. (2010). Minding the gap between feminist identity and attitudes: The behavioral and ideological divide between feminists and non-labelers. Journal of Personality, 78(6), 1895-1924. https://doi. org/10.1111/j.1467-6494.2010

Zucker, A. N. ve Landry, L. J. (2007). Embodied discrimination: The relation of sexism and distress to women's drinking and smoking behaviors. Sex Roles, 56, 193-203. 


\title{
Summary \\ Women's Responses to Sexism:Justification, Self-Silencing, Confrontation, and Collective Action
}

\author{
Nuray Sakall1 \\ Middle East Technical University
}

\begin{abstract}
Women are exposed to a variety of sexist behaviors in their daily lives. What kind of responses do women give to the sexist behaviors? Does women's awareness of sexism change their responses to sexism? What kind of social psychological variables influence women's responses? What are the positive or negative outcomes of women's responses? The purpose of the article is to review the literature on women's responses to sexism to answer these questions.
\end{abstract}

\section{Women's Responses to Sexism}

Briefly, sexism is defined as discrimination based on person's gender in social psychology literature. In general, researchers who study sexism generally focus on gender stereotypes, negative attitudes toward women, and discriminatory behaviors against women. Exposure to sexist behaviors may lead women to show various responses such as avoidance, self-blaming, humor, being silent, negotiation, warning, seeking social support, complaining to friends, and filling an official complaint (Fitzgerald, Swan, \& Fischer, 1995; Knapp, Faley, Eekberg, \& DuBois, 1997; Major, Quinton, \& McCoy, 2002). In the present paper, inspiring from the intergroup literature (Tajfel \& Turner, 1976; Wright et al., 1990), women's responses to sexism are covered under two main dimensions as the level of awareness of sexism and passive lactive strategies against sexism. Depending on the literature on sexism and responses to sexism, it is possible to indicate that women's responses may vary from passive acceptance to active collective actions and can be grouped under four main titles as

(1) acceptance and justification of sexism without awareness of sexism,

(2) self-silencing with awareness of sexism,

(3) confronting sexism with awareness of sexism,

(4) collective behavior against sexism with awareness of sexism.

\section{Acceptance and Justification of Sexism}

Although women are exposed to prejudice and discrimination (Swim et al., 2001), some of them are not aware of the existence of sexism. They conform to gender roles without questioning (Szymanski et al., 2009; Zucker \& Bay-Cheng, 2010), and support the existing gender system (Radke et al., 2016). They reject feminist views (Yeung et al., 2014). There are many social psychological theories to explain why some women accept and justify the existing gender system. These theories are ambivalent sexism (Glick \& Fiske, 1996), system justification (Jost \& Kay, 2005), social dominance (Pratto et al., 2006), and right-wing authoritarianism (Altemeyer, 1998).

\section{Self-Silencing}

Some women may be aware of sexism but still prefer to be silent (Kaiser \& Miller, 2004). Jack (1991) suggested that according to traditional gender roles, good women are supposed to fulfill others' needs first in their family and intimate relationships. Women who internalized traditional gender roles may present self-silencing to protect the gender system (Jack, 1991), and not to feel bad (Hyers, 2007). There may be many factors influencing self-silencing such as self-efficacy (Bandura, 1977), quality of intimate relationship (Whiffen et al., 2007), having feminist attitudes (Watson \& Grotewiel, 2016), having experiences of being seen as a sexual object (Watson et al., 2012), and rejection sensitivity (London et al., 2012).

\section{Confrontation}

Women who are aware of sexism may question and confront sexist behaviors of men and others. Confrontation is a way of dealing with a stressful event such as sexism. With confrontation, women try to change their target position (Kaiser \& Miller, 2004). Researchers have examined the association between confronta-

Address for Correspondence: Prof. Dr., Nuray Sakall1, Middle East Technical Unversity, Faculty of Arts and Sciences, Department of Psychology, Çankaya / Ankara

E-mail: nurays@metu.edu.tr 
tion and several social psychological variables such as awareness of sexism (Ashburn-Nardo et al., 2008), identification with their own gender (Major et al., 2003), and identification with feminists (Ayres et al., 2009). They have also searched the effects of type of sexist behavior, acquaintance (Ayres et al., 2009), characteristics of the situation (Swim \& Hyers, 1999), and perception of costs and benefits (Shelton \& Rocheson, 2005; Stangor et al., 2002) on confrontation.

Further, women who confront sexist behaviors may be judged negatively and less likely to be liked and respected. They may be perceived as cold, problematic, overreactive, and bad intention (Becker et al., 2011; Dodd et al., 2001). They may be even punished (Bergman et al., 2002).

\section{Collective Behavior against Sexism}

Some women may prefer collective action against sexism in order to solve not only an individual problem but also a group problem. As Wright et al. (1990) argued, if a behavior is performed to correct a group's disadvantaged social status by an individual, the behavior can be considered as collective behavior. From signing a petition to joining an active women organization, many behaviors can be accepted as collective action (Radke et al., 2016). There are several social psychological theories about collective actions such as relative deprivation (Crosby, 1976) and social identity (Tajfel \& Turner, 1979). Foster and Matheson (1995) found that women who feel both egoistic relative deprivation and fraternal relative deprivation perceive their group's disadvantaged positions and participate in collective action. Similarly, van Zomeren et al. (2008) suggest that identification, perceiving illegitimacy, and self-efficacy are necessary factors to create a social change. If women who identify with their own gender and perceive that the disadvantaged position of women is illegitimate may think that they can control their outcomes and contribute to social change in sexism; and so they are more likely to join collective action. In addition, researchers (Duncan, 1999; Zucker, 2004) have suggested that having feminist identity, blaming system, and feeling negatively about power predict collective action.

Even though feminist identity is necessary for collective action, some women have negative attitudes toward feminists. Feminists are perceived as aggressive, problematic, and forceful individuals (Beryyman-Fink \& Verderber, 1985; Yoder et al., 2011). They are seen as a threat to traditional social values (Cottrel \& Neuberg, 2005). Some women may try to disidentify with feminists (Redford et al., 2016). They may even say "I am not a feminist but I support gender equality."
In order to increase collective action tendencies, decreasing prejudice against feminists seems to be necessary. Researchers have demonstrated that exposure to feminist views (Nelson et al., 2008; Reid \& Purcell, 2004); having positive social contact with feminists (Reid \& Purcell, 2004), having a feminist mother (Nelson et al., 2008), taking a feminist course (Bargad \& Hyde, 1991; Nelson et al., 2008) may lead women to develop feminist identity.

Negative or Positive Outcomes of Responses to Sexism

As mentioned, justification of sexism, self-silencing, confrontation and collective behavior are four different main responses to sexism. These responses may bring various individual or group related positive or negative outcomes to women.

\section{Individual Based Negative and Positive Outcomes}

Focusing on the individual outcomes of responses to sexism, it is possible to observe that justification of sexism, especially benevolent sexism, may increase well-being of women (Hammond \& Sibley, 2011; Napier et al., 2010). However, benevolent sexism also leads women to question their abilities and performances (Dardenne et al., 2007; Dumont et al., 2010); to see themselves as an object (self-objectification; Calogero \& Jost, 2011); and to judge themselves by their appearance (Szymanski et al., 2009). These women, in return, may experience more discrimination.

Women who justify the gender system may experience many psychological (Moradi \& Subich, 2002), physical (Goldenhar et al., 1998) and sexual health problems (Yoder et al., 2007). Similarly, researchers have presented that women who silence themselves blame themselves more (Fairchild \& Rudman, 2008), and have depression (Jack, 1991). In contrast, women who confront are more likely to feel good about their confrontation (Hyers, 2007). They feel good and strong about themselves (Gervais et al., 2010). Similarly, collective behavior is positively correlated with well-being (Szymanski \& Owens, 2009).

\section{Group Based Positive and Negative Outcomes}

Justification of sexism and self-silencing block social change in gender system, and so women's disadvantaged position stays the same. Becker and Wright (2011) presented that women who strongly support benevolent sexism are less likely to have a motivation to decrease discrimination. Similarly, Dardenne et al. (2007) found that benevolent sexism lowers women's motivation and performances.

Confrontation and collective actions, however, are positively correlated with social change. As minori- 
ty influence literature (e.g., Moscovici, 1976) suggests minority groups such as women should create a conflict with the majority group (dominant gender system and men) in order to make the women's issues visible in the society. Confronting and collective action can be used as a way of creating awareness about sexism, and providing gender equality.

\section{Conclusion}

The article covers main women's responses to sexism, namely, justification of sexism, self-silencing, confrontation, and collective action. The motivation behind these responses might be relevant to avoiding conflict, protecting self-image, saving energy, presentation of self, and educating others (Hyers, 2007).

These different responses may be displayed by the same woman in different times. Personal social development and changes in attitudes may lead to each of these responses. A woman who justifies the gender system may internalize self-silencing for a while, but then she may confront to sexism because of some social experiences. She may move toward feminist ideology and join collective action (Downing \& Roush, 1985; Savaş \& Stewart, 2019).

There are many variables that influence women's responses to sexism. These variables can be combined under individual, situational and contextual varaibles. In terms of individual variables, both women's and others' attitudes, attribution style, commitment to social norms, and levels of awareness may exert influence on women's responses to sexism. In addition, where the sexist event occurs is very important for women's reactions. Culture may be highly associated with women's responses.

Further, responses to sexism may consist of cognitive, affective and behavioral components and so are highly relevant to attitude change literature. Several attitude change theories (e.g., Elaboration Likelihood Model of Petty and Caccioppo, Social Judgment Theory of Muzaffer Sherif, Psychological Reactance of Jack Brehm) can be applied to responses to sexism and change in sexism issues.

Finally, it is important to understand women's responses to sexism and how to create a social environment in which women can easily show their reactions to sexist behaviors. Education, politics, and laws should provide a safe environment for women to present these responses. In addition, researchers from different disciplines such as psychology, sociology, women/gender studies, and politics should search women's responses and attitude change in sexism, especially in Turkey. 